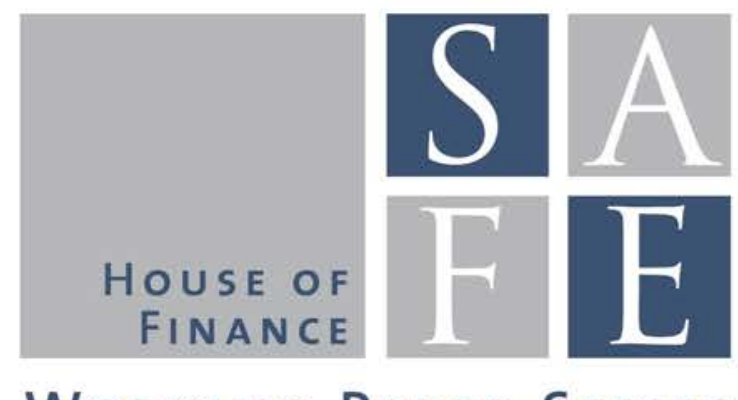

WORKING PAPER SERIES

Tobias H. Tröger

\title{
Too Complex to Work: A Critical Assessment of the Bail-in Tool under the European Bank Recovery and Resolution Regime
}

SAFE Working Paper No. 179

SAFE I Sustainable Architecture for Finance in Europe A cooperation of the Center for Financial Studies and Goethe University Frankfurt 


\section{Too Complex to Work}

\section{A Critical Assessment of the Bail-in Tool under the European Bank Recovery and Resolution Regime}

(August 20, 2017)

Tobias H. Tröger

Professor of Private Law, Trade and Business Law, Jurisprudence

Goethe-University, Frankfurt am Main, Department of Law

Theodor-W.-Adorno Platz 3

60629 Frankfurt am Main

\section{Germany}

Phone +496979834236

Fax +496979834536

troeger@jur.uni-frankfurt.de

Abstract: This paper analyses the bail-in tool under the BRRD and predicts that it will not reach its policy objective. To make this argument, this paper first describes the policy rationale that calls for mandatory private sector involvement (PSI). From this analysis the key features for an effective bail-in tool can be derived. These insights serve as the background to make the case that the European resolution framework is likely ineffective in establishing adequate market discipline through risk-reflecting prices for bank capital. The main reason for this lies in the avoidable embeddedness of the BRRD's bail-in tool in the much broader resolution process which entails ample discretion of the authorities also in forcing private sector involvement. Finally, this paper synthesized the prior analysis by putting forward an alternative regulatory approach that seeks to disentangle private sector involvement as a precondition for effective bank-resolution as much as possible from the resolution process as such.

Keywords: bail-in, private sector involvement, precautionary recapitalization, cross-border insolvency, market discipline

JEL classification: G01, G18, G21, G28, K22, K23 


\section{Too Complex to Work}

A Critical Assessment of the Bail-in Tool under the European Bank Recovery and Resolution Regime

Tobias H. Tröger

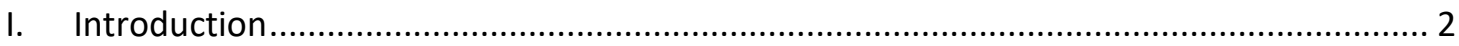

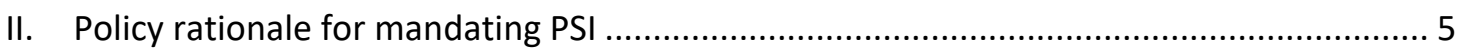

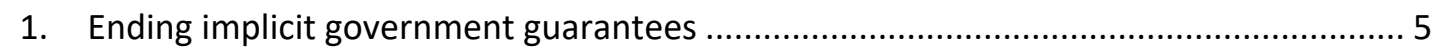

a) Bail-out rationality and defunct debt-governance ........................................... 5

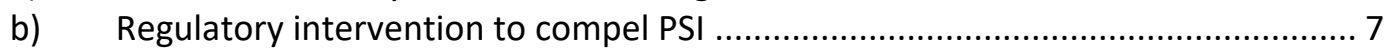

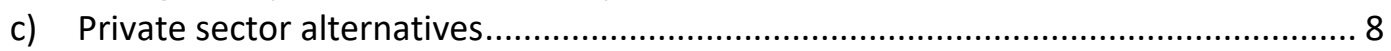

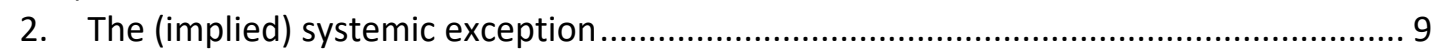

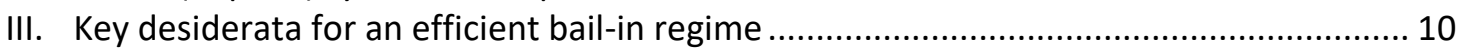

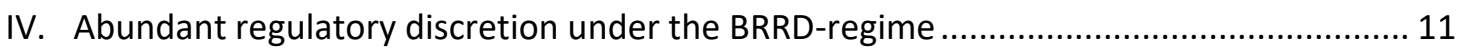

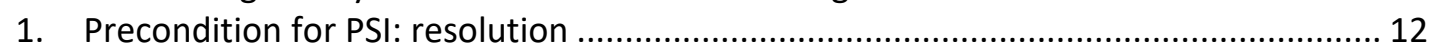

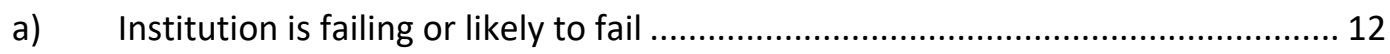

b) No prospect to prevent failure ................................................................. 14

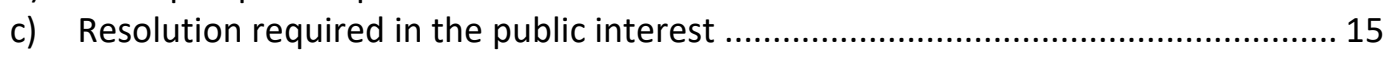

d) Competence to determine conditions for resolution ...................................... 16

2. Application of bail-in tool after triggering resolution ................................................ 17

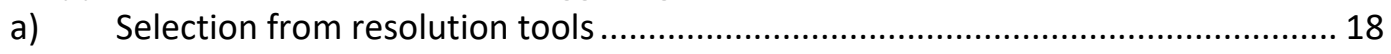

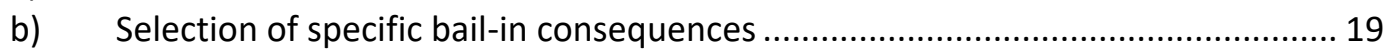

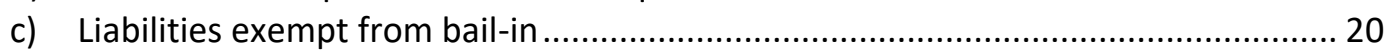

(1) Exemptions by law ............................................................................. 20

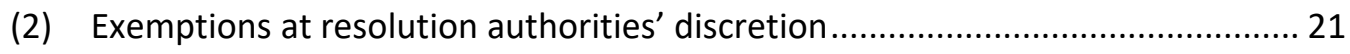

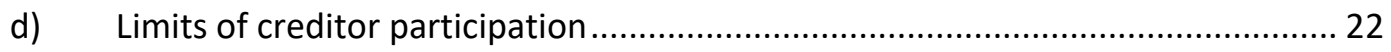

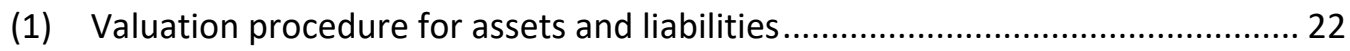

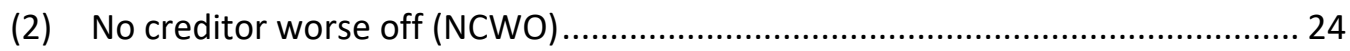

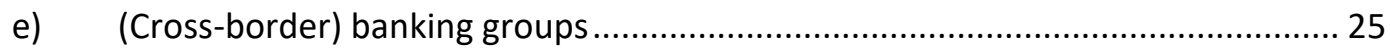

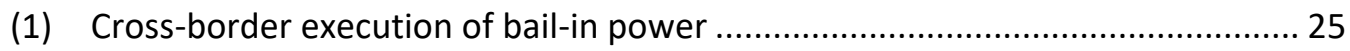

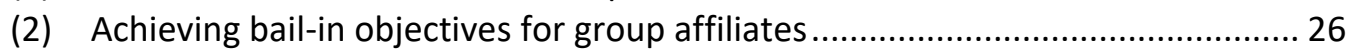

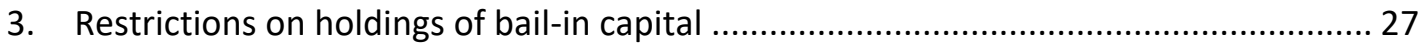

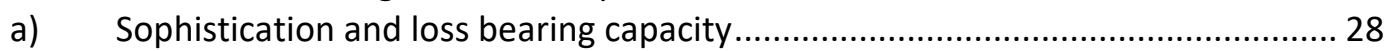

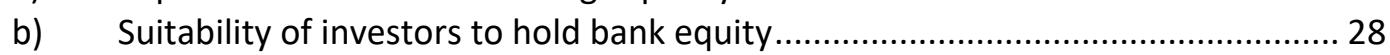

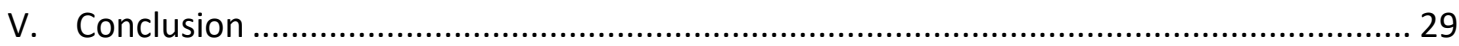

* Professor of Private Law, Trade and Business Law, Jurisprudence, Goethe University Frankfurt am Main, Program Director Research Center Sustainable Architecture for Finance in Europe (SAFE). Associated Professor Institute of Monetary and Financial Stability (IMFS). The author gratefully acknowledges financial support of the LOEWE Research Center SAFE. 


\section{Introduction}

After the financial crises of 2007 and 2008 governments around the world vowed to end "too big to fail" (TBTF) and avert the moral hazard problems arising from anticipated bail-outs. ${ }^{1}$ A main pillar of the regulatory strategy to achieve this goal was to enhance resolution frameworks and thus make failure an option even for the largest financial institutions. ${ }^{2}$ If indeed a failing bank could be wound-down or reorganized without implications for financial stability, a bail-out with taxpayers' money was no longer warranted as a matter of sound banking policy. Therefore, the private sector would have to bear the losses the ailing institution incurred. This would not only preserve public finances ex post but also instill market discipline ex ante. Investors would price bank capital with a view only to the default probability as determined in the asset valuation process and not in light of distorting implicit government guarantees. ${ }^{3}$

${ }^{1}$ The first notice of intent occurred at the G20 summit in Pittsburgh 2009, see G20 Leaders Statement, The Pittburgh Summit (2009), 9 <https://www.oecd.org/g20/summits/pittsburgh/G20-Pittsburgh-Leaders-Declaration.pdf> accessed 20 August 2017. For key policy documents see Financial Stability Board (FSB), Reducing the moral hazard posed by systemically important financial institutions (2010) 3-6 <http://www.fsb.org/wp-content/uploads/r_101111a.pdf> accessed 20 August 2017; High-level Expert Group on reforming the structure of the EU banking sector, Final Report (2012) 81-83, 92-93 <http://ec.europa.eu/finance/bank/docs/high-level_expert_group/report_en.pdf> accessed 20 August 2017; Paul Tucker, 'Resolution and the Future of Finance' (The Hague, 20 May 2013) <http://www.bis.org/review/r130606a.pdf>; see also Thomas F. Huertas, Safe to Fail (Palgrave Macmillan 2014) 4-20 (describing the negative growth implications of TBTF); for a review of the academic literature see Philip E Strahan, 'Too Big to Fail: Causes, Consequences,and Policy Responses', (2013) 5 Annual Review of Financial Economics 43-61.

${ }^{2}$ For a discussion of the essential features of an adequate policy framework to counter the TBTF-problem see Inci Ötker-Robe et al., 'The Too-Important-to-Fail Conundrum: Impossible to Ignore and Difficult to Resolve', International Monetary Fund (IMF) Staff Discussion Note SDN/11/02, 10-21 <https://www.imf.org/external/pubs/ft/sdn/2011/sdn1112.pdf> accessed 20 August 2017.

${ }^{3}$ For a more granular description of the policy rationale, see II. 1. 
The introduction of the bail-in tool, ${ }^{4}$ which compels investors in bank capital to absorb the losses of a failing institution according to a predetermined waterfall ${ }^{5}$ and thereby to assume the primary burden in the bank's recapitalization, is a cornerstone of the reform agenda. ${ }^{6}$ Only if a credible device for achieving such a significant private sector involvement (PSI) in bank resolution without conjuring-up threats for financial stability existed, markets would discard the possibility of a government intervention to support bank capital. From a functional perspective, it is less relevant at the outset whether PSI occurs as part of a resolution that ultimately leads to the termination of the failed legal entity (gone-concern basis) or under a regime that allows the ailing institution to stay open through and after resolution (going-concern basis, open-bank bail-in). ${ }^{7}$ Regardless of the legal form in which the valuable parts of the failed bank's business continue, ${ }^{8}$ the losses that compromised the institution's viability and triggered resolution have to and can be fully allocated to existing investors in the bank's capital instruments. PSI can be achieved either by bailing-in parts of the liabilities linked to the sold or

${ }^{4}$ The basic concept of private sector burden sharing predates the recent financial crisis see for instance Barry Eichengreen and Christoph Ruehl, 'The Bail-In Problem: Systematic Goals, Ad Hoc Means' (2001) 25 Econ Systems 3. The development of the contemporary, bank-specific implementations is frequently credited to a financial press contribution, see Paul Calello and Wilson Ervin, 'From Bail-Out to Bail-In' The Economist (London, 28 January 2010) 95.

${ }^{5}$ For instance Directive 2014/59/EU of the European Parliament and of the Council of 15 May 2014 establishing a framework for the recovery and resolution of credit institutions and investment firms and amending Council Directive 82/891/EEC, and Directives 2001/24/EC, 2002/47/EC, 2004/25/EC, 2005/56/EC, 2007/36/EC, 2011/35/EU, 2012/30/EU and 2013/36/EU, and Regulations (EU) No 1093/2010 and (EU) No 648/2012, of the European Parliament and of the Council [hereinafter: BRRD], art. 44, [2014] OJ L173/190.

The special resolution regime for systemically important financial institutions (SIFIs) in the U.S. implements PSI rather indirectly: $\S 210(a)(1)(M)$ of the Dodd-Frank Wall Street Reform and Consumer Protection Act [hereinafter: DFA], 12 U.S.C. $§ 5390(a)(1)(M)$ allows the Federal Deposit Insurance Corporation (FDIC) to "terminate all rights and claims" of stockholders and creditors against the failed institution. Yet, the main mechanism for private sector burden sharing is a compelled transfer of assets: If no private sector purchaser is available, most of the failed bank holding company's assets are transferred to an intermediate bridge company while the bulk of liabilities remains in the estate and claimants against the bank holding company will only receive stock of this bridge company to satisfy their claims. This concept was developed in FDIC, 'The Resolution of Systemically Important Financial Institutions: The Single Point of Entry Strategy', (2013) 78 Fed Reg 76614; for a description Jeffrey N. Gordon and Wolf Georg Ringe, 'Bank Resolution in the European Banking Union: A Transatlantic Perspective on What it Would Take' (2015) 115 Colum.L.Rev. 1297, 1325-1330.

${ }^{6}$ Ötker-Robe et al. (n 2) 20-21. The DNA of the European regime stems from the FSB, Key Attributes of Effective Resolution Regimes for Financial Institutions (2011) Section 3.5 and $3.6<$ http://www.fsb.org/wp-content/uploads/r_111104cc.pdf> which remained unchanged in the most recent version, FSB, Key Attributes of Effective Resolution Regimes for Financial Institutions (2014) Section 3.5 and $3.6<$ http://www.fsb.org/wp-content/uploads/r_141015.pdf> accessed 20 August 2017.

7 The U.S. resolution framework does not know any other outcome than the liquidation of the failing institution, see DFA, § 204(a), 12 U.S.C. $\$ 5384(a)$, which does not exclude a temporary continuation of its operations. To be sure, writing-off equity and debt under the specific liquidation regime can be executed to facilitate a sale of assets to a third-party, DFA, $\S 210(a)(1)(D), 12$ U.S.C. $\S 5390(a)(1)(D)$, or the transfer of assets to a bridge financial company, DFA, $\S 210(\mathrm{a})(1)(\mathrm{F}), 12$ U.S.C. $\S 5390(\mathrm{a})(1)(\mathrm{F})$, and thus supports resolution strategies that allow viable businesses to survive, yet not the failing institution (legal entity). Therefore, the only resolution strategy that is not available under DFA but under the BRRD is the open-bank bail-in.

${ }^{8}$ They can be purchased and assumed by another legal entity, transferred to a bridge institution, or operated by the reorganized bank after resolution. 
transferred operations and sending the original bank into liquidation, ${ }^{9}$ or by fully bailing-in investors in order to achieve a sustainable capital structure for the original legal entity. ${ }^{10}$

However, translating conclusive policy recommendations into operable regulation (law) has its own intricacies. Desirable market discipline can only be induced if investors can predict the risk of their capital instruments being written-off or converted with reasonable certainty. To be sure, a significant amount of uncertainty is inherent in the pertinent determinations as a result of their forecasting nature, which is particularly true if conversion creates a potential upside in the future. Yet, these inevitable difficulties that stem from projecting a financial institution's destiny (failure and resurrection) should not be aggravated by a complex and highly discretionary regulatory framework for PSI. Predicting the timing and outcome of resolution should not require a wild guess. Otherwise, investors would find it even harder to determine expected losses in a bail-in. The prices of the relevant financial instruments would be a noisy indicator for the default risks associated with the investment and hence the effect of "market discipline" would be ambiguous as well.

Unfortunately, the bail-in tool under the BRRD and the Single Resolution Mechanism Regulation (SRM-Reg) ${ }^{11}$ provides for a highly complicated and detailed regulatory framework that gives a multitude of authorities ample discretion in compelling PSI and requires significant inter-agency cooperation and information sharing. The publicly administered ad hoc bail-in tool under the BRRD complicates the prediction of outcomes and thus impairs an optimal implementation of the main policy objectives legislators pursued in the regulatory overhaul that reacted to the financial and sovereign debtcrises. Even more dramatically, an in depths analysis of the pertinent provisions warrants the prediction that the bail-in tool under the BRRD is likely to fail. An alternative approach should seek to disentangle PSI as a precondition for effective bank-resolution as much as possible form the resolution process as such.

To make this argument, this paper first describes the policy rationale that calls for mandatory PSI with a particular view to the trade-off between ending implicit government guarantees and safeguarding financial stability (II.). From this analysis the key features for an effective bail-in tool can be derived that lie in a design of the bail-in tool that facilitates the ex ante prediction of outcomes for investors in bail-in capital and a close monitoring of bail-in capital holdings that should only be found in the portfolios of suitable investors (III). These insights serve as the background to make the case that the European resolution framework is likely ineffective in establishing adequate market discipline through risk-reflecting prices for bank capital. The main reason for this lies in the avoidable embeddedness of the BRRD's bail-in tool in the much broader resolution process (IV). The conclusion shows briefly that the regulatory prescription of even a sufficiently large layer of bail-in capital cannot fully solve the problem and puts forward the alternative regulatory proposal which synthesizes the prior insights (V).

${ }^{9}$ The U.S. resolution regime, which necessarily leads to the failed institution's liquidation, lays down the guiding principle in DFA, § 204(a)(1), § 12 U.S.C. § 5384(a)(1) (stating that "creditors and shareholders will bear the losses of the financial company") and thus ultimately leads to the complete allocation of the failed bank's liabilities to its equity- and debtholders, just like in ordinary insolvency proceedings; but see also n 123.

${ }^{10}$ See BRRD, art. 46(2) and IV. 2. d) (1).

${ }^{11}$ Regulation (EU) No 806/2014 of the European Parliament and of the Council of 15 July 2014 establishing uniform rules and a uniform procedure for the resolution of credit institutions and certain investment firms in the framework of a Single Resolution Mechanism and a Single Resolution Fund and amending Regulation (EU) No 1093/2010 [2014] OJ L225/1. 


\section{Policy rationale for mandating PSI}

This section briefly revisits the policy rationale that underpins mandatory PSI in bank resolution and delineates the relation between effective recapitalization of the failing bank and the re-establishment of market-discipline (1). It also pays particular attention to the limits that follow from the paramount objective to resolve failing banks without creating financial instability (2).

\section{Ending implicit government guarantees}

\section{a) Bail-out rationality and defunct debt-governance}

The default of a SIFI may impact on the national or global financial system. ${ }^{12}$ A SIFI's failure can affect other financial institutions because (i) it is a counterparty for many other market participants, (ii) it is forced to fire-sell assets which lead to depressed prices for assets that other institutions use as collateral (demand for higher margins), (iii) its default sparks a panic that spreads to other institutions. ${ }^{13}$ These consequences, in turn, carry over to the real economy. ${ }^{14}$ If the proper functioning of the financial sector is impaired, for instance, because interbank lending dries-up when confidence in borrowers' viability dwindles, financials start to stash cash and the real economy receives less liquidity to finance productive activities. The lack of credit drives down total output, the ensuing growth and welfare losses ultimately imperil political stability and democracy. In this scenario, government interventions that take the form of bank bail-outs at an early stage are a fully rational reaction to imminent threats. Yet, bank rescues with government money imperil financial stability if they lead to unsustainable public finances: Banks with significant exposure to sovereign debt will experience further solvency stress (bank-sovereign feedback loop). ${ }^{15}$

Moreover, the economic logic that motivates bail-outs also allows markets to anticipate government behavior and thus factor in an implicit government guarantee in the price of bank capital. This tacit guarantee provides a lower bound to the value of assets on a bank's balance sheet and thus shifts the default probability downward compared to a model with endogenously determined (asset valuation process) bank failure. Banks that benefit from implicit guarantees - because they are deemed TBTF - enjoy lower risk premiums and can thus raise capital from rational investors at lower

12 To be sure, even the failure of large banks must not necessarily trigger systemic implications, see Joseph H Sommer, 'Why Bail-In? And How!', (2014) 20 FRBNY Eco Pol Rev 207, 214 (stressing that even “megabanks" often collapse in isolation and go down smoothly).

${ }^{13}$ For illustrations of all types of systemic impact during the financial crisis of 2007 and 2008 see Markus Brunnermayer, 'Deciphering the Liquidity and Credit Crunch 2007-08', (2009) 23 JEP 77-100; Darrell Duffie, How Big Banks Fail and What to Do About it (Princeton, Princeton University Press 2010) 23-36; Viral Acharya, Hyun S. Shin, and Tanju Yorulmazer, 'Crisis Resolution and Bank Liquidity' (2011) 24 Rev Fin Stud 2166-2205; Gary Gorton and Andrew Metrick, 'Securitized Banking and the Run on Repo' (2012) 104 JFE 425-451.

${ }^{14}$ For a detailed description of the macro-economic links between the financial system and the real economy that precipitate policy makers' incentives to bail-out SIFIs Jonathan R. Macey and James P. Holdcroft, Jr., 'Failure Is an Option: An Ersatz-Antitrust Approach to Financial Regulation' (2011) 120 Yale L.J. 1368, 137583; Tobias H. Tröger, 'Organizational Choices of Banks and the Effective Supervision of Transnational Financial Institutions' (2013) 48 Tex.Int'I L.J. 178, 187-190. But see also Mathias Dewatripont, 'European Banking: Bail-out, Bail-in and State Aid Control' (2014) 34 Int J of Indus Org 37, 39-40 (showing that the social costs of bail-out restrictions potentially comprise losses in total output caused by lasting instability).

15 Jianping Zhou et al., 'From Bail-out to Bail-in: Mandatory Debt Restructuring of Systemic Financial Institutions', (2012) International Monetary Fund (IMF) Staff Discussion Note SDN/12/03, 4 <https://www.imf.org/ /media/Websites/IMF/imported-full-text-pdf/exter-

nal/pubs/ft/sdn/2012/_sdn1203.ashx> accessed 20 August 2017; Emilios Avgouleas and Charles Goodhart, 'A Critical Evaluation of Bail-Ins as Bank Recapitalisation Mechanisms' (2014) Centre for Economic Policy Research (CEPR) Discussion Paper 10065, 1 <http://ssrn.com/abstract=2478647> accessed 20 August 2017. 
prices. ${ }^{16}$ Distorted market pricing bears on the liability side of banks' balance sheets because they can raise capital at prices that are insensitive to their risk-taking behavior and thus serve the appetite of equity holders to build leverage. ${ }^{17}$ Hence, the government subsidy allows banks and their equity holders to fund excessive risk-taking (moral hazard) and thus leads to inefficient investment decisions on the asset side of their balance sheet. ${ }^{18}$ In essence, debt-governance does not work, because financial institutions' risk bearing capacity does not drive the pricing of their capital (no market discipline). ${ }^{19}$ Moreover, the government put that drives the price of bank debt if bail-outs are the default way of dealing with banking crises makes banks' funding costs hinge on the fiscal strength of the respective sovereign and thus hampers a level playing-field for the provision of financial services. ${ }^{20}$

${ }^{16}$ For empirical evidence of the effect see Donald P. Morgan and Kevin J. Stiroh, 'Too Big to Fail After All These Years' (2005) FRBNY Staff Report No. 220 <https://www.newyorkfed.org/medialibrary/media/research/staff_reports/sr220.pdf> accessed 20 August 2017 (showing that the relationship between bond spreads and ratings was lower for TBTF-banks than for other financial institutions during the 1990s); Kenichi Ueda and Beatrice Weder-Di Mauro, 'Quantifying the Value of the Subsidy for Systemically Important Financial Institutions' (2012) IMF Working Paper Nor. 12/128 <http://www.imf.org/ /media/Websites/IMF/imported-full-text-pdf/external/pubs/ft/wp/2012/_wp12128.ashx> accessed 20 August 2017 (estimating an increase from 60 to 80 basis points between 2007 and 2009 in the structural subsidy as measured in big banks credit ratings); Zoe Tsesmelidakis and Robert C. Merton, 'The Value of Implicit Guarantees', (2012) Working Paper <http://ssrn.com/abstract=2231317> accessed 20 August 2017 (estimating the funding advantage of 74 U.S. financials benefiting from implicit government guarantees to sum up to $\$ 365 \mathrm{bn}$.); Frederick A. Schweikhard and Zoe Tsesmelidakis (2012), 'The Impact of Government Interventions on CDS and Equity Markets', American Finance Association 2012 Chicago Meetings Working Paper <http://ssrn.com/abstract=1573377> accessed 20 August 2017 (showing how model-estimated risk premiums for bank debt deviated significantly from actual market premiums charged for major U.S. banks in CDS-markets through the financial crisis); João A.C. Santos, 'Evidence from the Bond Market on Banks' "Too-Big-To-Fail" Subsidy" (2014) 20(2) FRBNY Econ. Pol'y Rev. 29 (showing that between 19852009 investors accepted significantly lower spreads on bonds issued by the US largest banks than on bonds issued by small banks). For an estimation of the potential impact credible PSI through bail-in would have according to standard rating methodology see Frank Packer and Nikola Tarashev, 'Rating Methodologies for Banks', (June 2011) BIS Q Rev 39, 50.

${ }^{17}$ On the basic incentive structure that is rooted in the ability to shift risk to existing creditors see for instance Anat R. Admati et al., 'Fallacies, Irrelevant Facts, and Myths in the Discussion of Capital Regulation: Why Bank Equity is Not Socially Expensive', (2013) Max Planck Institute for Research on Collective Goods 2013/23; Rock Center for Corporate Governance at Stanford University Working Paper No. 161; Stanford University Graduate School of Business Research Paper No. 13-7, 3 <https://ssrn.com/abstract=2349739> accessed 20 August 2017.

${ }^{18}$ For evidence see Blaise Gadanetz, Kostas Tsatsaronis, and Yener Altunbaş, 'Spoilt and Lazy: The Impact of State Support on Bank Behavior in the International Loan Market' (2012) 8 Int'I J Central Bank. 121; Luis Brandao-Marques, Ricardo Correa, and Horacio Sapriza, 'International Evidence on Government Support and Risk Taking in the Banking Sector' IMF Working Paper No. 13/94 <http://www.imf.org/external/pubs/cat/longres.aspx?sk=40501>, accessed 20 August 2017; Gara Afonso, João A.C. Santos, and James Traina, 'Do "Too-BigTo-Fail" Banks Take on More Risk?' (2014) 20(2) FRBNY Econ Pol Rev 41. On the anticompetitive effect of the subsidy that allows big banks to push smaller competitors out oft he market by aggressively cutting margins, see Reint Gropp, Hendrik Hakenes and Isabel Schnabel, 'Competition, Risk-shifting, and Public Bail-Out Policies' (2011) 24 RFS 2084.

${ }^{19}$ The effect was first modelled with regard to explicit government guarantees (deposit insurance), Robert C. Merton, 'An Analytical Derivation of the Cost of Deposit Insurance and Loan Guarantees' (1977) 1 JBF 311; Robert C. Merton and Zvi Bodie, 'Deposit Insurance Reform: A Functional Approach' (1993) 38 CarnegieRochester Conference on Public Policy 1-34, but can be generalized, see eg Tobias Adrian and Adam B. Ashcraft, 'Shadow Banking Regulation' (2012) Federal Reserve of New York Staff Reports No. 559, 8-10 <http://www.newyorkfed.org/research/staff_reports/sr559.pdf> accessed 20 August 2017.

${ }^{20}$ See Zhou et al. (n 15) 20-21. 


\section{b) Regulatory intervention to compel PSI}

The observable market failure warrants regulatory intervention. The bail-in tool seeks to address the root cause of the problem: its objective is to credibly ensure PSI in a bank's failure, that is, to compel risk bearing of agents who provide banks' capital. ${ }^{21}$ If effective, it undoes government guarantees (no bail-out). It thus ensures that banks' funding is sensitive to the risks they are running and puts an end to excessive risk-taking, overinvestment etc. induced by moral hazard. ${ }^{22}$

The indispensable precondition for such a regime to work is that the bail-in tool allows losses to be passed-on to investors in bank capital in a way that does not shatter the confidence of bank clients in the continuous provision of critical financial services (liquidity provision, insurance-type riskshifting) throughout and beyond resolution. In other words, PSI must not impair the (short- to mediumterm) viability of the essential functions of the resolved institution. Only under this precondition, it can prevent overly disruptive effects of bank failure. ${ }^{23}$ After all, bankruptcy law also allocates losses to the insolvent entity's creditors, yet it does so without paying attention to the peculiarities of financial institutions. ${ }^{24}$ Instead, a bank-dedicated regime for PSI would carefully avoid destroying the additional value that certain liabilities of banks convey to the claimholder beyond the rights to future cashflows. ${ }^{25}$ It would provide for an instantaneous (overnight) recapitalization that leaves critical operations intact, which also requires paying tribute to large banks' interconnectedness and cross-border

21 John C. Coffee, Jr., 'Bail-Ins Versus Bail-Outs: Using Contingent Capital to Mitigate Systemic Risk', (2010) Columbia Law and Economics Working Paper No. 380, 35 <http://ssrn.com/abstract=1675015> accessed 20 August 2017; Zhou et al. (n 15) 5, 20; Thomas F. Huertas, 'The Case for Bail-ins' in Andreas Dombret and Patrick S. Kenadjian (eds.), The Bank Recovery and Resolution Directive - Europe's Solution for "Too Big To Fail"? (de Gruyter 2013) 167, 168; Avgouleas and Goodhart (n 15) 2; Karl-Philipp Wojcik, 'Bail-in in the Banking Union' (2016) 53 CMLR 91, 107; see also Zhou et al. (n 15) 7 (describing bail-in as a concept of insurance provided by subordinated term debtors); Gordon and Ringe (n 5) 1355-6 (same). The description of PSI as a 'penalty for failure' imposed on investors in bank capital, eg Avgouleas and Goodhart ( $\mathrm{n} 15$ ) 2, can be misleading because bailin does primarily aim at an efficient allocation of risk and does not express any normative judgement as to who is to blame for the bank's failure.

22 See also Tobias H. Tröger, 'Regulatory Influence on Market Conditions in the Banking Union: the Cases of Macro-Prudential Instruments and the Bail-in Tool' (2015) 16 EBOR 575, 588 figure 3.

${ }^{23}$ Bail-in can be understood as an instrument to facilitate a large bank's (financial conglomerate's) swift recapitalization that prevents liquidity stress and thus averts fire sales and the disorderly liquidation of financial contracts ("runs"), Zhou (n 15) 5, 7; Sommer (n 12) 217-223; Wojcik (n 21) 92, 107; see also Jens Hinrich Binder, 'Resolution: Concepts, Requirements and Tools' in Jens Hinrich Binder and Dalvinder Singh (eds.), Bank Resolution: The European Regime (Oxford OUP 2016) 25, 55-56 para 2.57 (emphasizing that bail-in preserves the incentives attributed to insolvency proceedings but avoids disruptive effects).

${ }^{24}$ For a theoretical discussion that complex and time-consuming bankruptcy proceedings under regular insolvency laws are apt to undermine confidence and destabilize markets see Andrei Schleifer and Robert Vishny, 'Fire Sales in Finance and Macroeconomics' (2011) 25 JEP 29-48; for specific assessments of the ineptness of the US Chapter 11 proceedings see Sommer (n 12) 225-228; for a comprehensive project seeking to propel bank specific amendments to the US bankruptcy code see Thomas H. Jackson, 'Bankruptcy Code Chapter 14' in Kenneth E Scott and John B. Taylor (eds.), Bankruptcy Not Bailout (Hoover Institution Press, 2012) 25-70; for a precrisis statement to the contrary see David A Skeel, 'The Law and Finance of Bank and Insurance Insolvency Regulation' (1998) 76 Tex L Rev 723; for post-crisis proponents of Chapter 11 proceedings for banks Kenneth Ayotte and David A Skeel, 'Bankruptcy or Bailouts? (2009) 35 J Corp L 469; Stephen J Lubben, 'Systemic Risk and Chapter 11' (2009) Temp L Rev 433; Douglas G Baird and Edward R Morrison, 'Dodd-Frank for Bankruptcy Lawyers' (2011) 19 Am Bankr Inst L Rev 287.

${ }^{25}$ Critical client relations appear on the liability side of the failed bank's balance sheet. Therefore, their treatment in ordinary insolvency law would destroy value beyond the nominal value of the claim. For instance, the automatic stay impairs the liquidity providing function of deposits and the loss participation of risk-shifting derivatives destroys hedges, see Sommer (n 12) 209-213 (highlighting the specific characteristics of "financial liabilities" whose social value exceeds their nominal one and may have a firm-specific element). Hence, the cost- 
group structure. ${ }^{26}$ It is important to understand that this lightning-speed recapitalization is distinct from the significantly more time-consuming determination of the fate of the failed organization later down the road. ${ }^{27}$

As a consequence, on informationally efficient markets that cannot be deluded by specific "labels", it doesn't matter if the pivotal stabilization of trust is achieved by a regime for the orderly liquidation of the failed legal entity that pays close attention to the peculiarities of the financial sector or a resolution procedure that does the same but keeps the failed institution open as a going-concern. ${ }^{28}$ The only aspect that matters is that the resolution framework credibly eliminates incentives for a disorderly termination of financial contracts in run-like scenarios that potentially stretch beyond the troubled institution.

\section{c) Private sector alternatives}

At least in theory, the goals pursued with a statutory bail-in tool that vests the discretionary power to write-down or convert liabilities with resolution authorities could also be achieve if the regulator compelled financial institutions to issue a sufficiently high amount of contingent capital instruments with respective features. ${ }^{29}$ From this perspective, it is a question of institutional design, whether private financial contracting, if initiated and overseen by regulators, will achieve desirable outcomes or whether a stronger role for public authorities with comprehensive decision making powers is preferable. It should be noted though, that also a statutory bail-in tool requires a minimum prescription of debt instruments subject to bail-in, ${ }^{30}$ which in turn has to consider private contracting solutions because of their functional complementarity. ${ }^{31}$ Hence, no regime releases regulators from the difficult task to project the potential recapitalization needs of individual financial institutions.

minimizing social optimum can only be achieved if these liabilities receive a special (preferred) treatment in insolvency); Avgouleas and Goodhart (n 15) 12 (same, with diverging terminology).

${ }^{26}$ Sommer (n 12) 213-214.

27 See also Sommer (n 12) 219 with table 1.

${ }^{28}$ Sommer (n 12) 219, 223 (seeing the orderly liquidation of a failed organization as a success because it preserves financial stability). For a different view that emphasizes the advantages of resolution on a goingconcern basis, Zhou et al. (n 15) 9.

${ }^{29}$ For a discussion of the policy rationale that underpins contingent capital and is identical with that of a statutory bail-in tool see Darell Duffie, 'A Contractual Approach to Restructuring Financial Institutions' in George P. Schultz, Ken E. Scott, and John B. Taylor (eds.), Ending Government Bailouts as We Know Them (Hoover Institution Press, 2010), 109, 109-110; Ceyla Pazarbasioglu et al., 'Contigent Capital: Economic Rationale and Design Features' (2011) IMF Staff Discussion Note SDN/11/01, 7-8 <https://www.imf.org/exter$\mathrm{nal} / \mathrm{pubs} / \mathrm{ft} / \mathrm{sdn} / 2011 / \mathrm{sdn} 1101$.pdf > accessed 20 August 2017; for the original vision, largely dwelling on the market-disciplining effect of contingent capital see Mark J. Flannery, 'No Pain, No Gain? Effecting Market Discipline via 'Reverse Convertible Debentures" in: Hal S. Scott (ed.), Capital Adequacy Beyond Basel: Banking: Securities, and Insurance (OUP 2005), 171, 173, 175-182.

${ }^{30}$ On the relevant rules that prescribe a minimum Total Loss Absorbing Capacity (TLAC) or set up Minimum Requirements for Own Funds and Eligible Liabilities (MREL) see Tobias H. Tröger, 'Why MREL Won't Help Much', SAFE Working Paper No. 180 <http://ssrn.com/abstract=3023185> accessed 20 August 2017.

${ }^{31}$ For the recognition of "contractual bail-in instruments" for the fulfillment of MREL see BRRD, art. 45(13). On the complementarity see also Zhou et al. (n 15) 6 (arguing that contingent capital could be a first line of defense before statutory bail-in applies). 


\section{The (implied) systemic exception}

Bank resolution without injection of public funds poses a problem if it occurs in the middle of a systemic crisis. In fact, financial history teaches that a tough stance of governments who refuse to backstop the financial system aggravates the impact of the event. ${ }^{32}$ Hence, any regime that seeks to compel PSI applies only under the condition - either expressly stipulated in the statutory foundations or included as an implied term - that no systemic crisis looms absent government intervention. The key question hence is how to balance the inevitable systemic exception with the overarching goal of instilling market discipline. In other words, how can regulators provide a safety valve without sacrificing the credibility of the regime altogether ? $^{33}$ The answer certainly is not an easy one, but has to carefully consider how even a well-designed PSI might indeed contribute to system-wide adverse effects. ${ }^{34}$

If investors are fully rational, bail-in as such does not trigger a systemic crisis, because its mechanics confine loss bearing. ${ }^{35}$ This is certainly true if bail-in is limited to one institution, however large. Yet, even where a higher number of banks fail, for instance because information revelation at one bank causes sector-wide mark-downs of certain assets, recapitalization through PSI remains a plausible element of the strategy to extinguish the fire. The only precondition is that the sector has issued adequate capital subject to bail-in and central bank liquidity (emergency lending) is available in sufficient proportions to establish trust in the short-term solvency of the organizations, ${ }^{36}$ which investors' loss bearing has adequately recapitalized. Of course, shocks to the financial system may reach proportions that exceed even such far-reaching safeguards, yet it has to be carefully monitored if indeed such a black swan materialized.

Moreover, if rationality assumptions are relaxed, runs may occur even if investors have no verifiable reason to believe that their institution is in trouble. ${ }^{37}$ Limiting negative effects of haircuts imposed on creditors of failing banks thus also requires attenuating (irrational) fears that PSI will also

32 The conventional wisdom is informed by the Federal Reserve's policy mistakes (allowing monetary contraction also by letting banks fail across the board) in the run-up to and during the Great Depression, see for instance Lester V. Chandler, American Monetary Policy 1928 to 1941 (1971, Harper and Row); Barry Eichengreen, 'The Origins and Nature of the Great Slump Revisited', (1992) 45 Econ. Hist. Rev. 213-239; Christina D. Romer, 'The Nation in Depression' (1993) 7 JEP 19-39; Ben S. Bernanke, The Macroeconomics of the Great Depression: A Comparative Approach' in Ben S. Bernanke (ed.), Essays on the Great Depression (Princeton University Press, 2000) 5-38.

${ }^{33}$ See Daniel Gros, 'The SRM and the dream to resolve banks without public money' (2013) Center for Economic Policy Studies (CEPS) Commentary <https://www.ceps.eu/system/files/DG\%20SRM\%20and\%20the\%20dream\%20to\%20resolve\%20banks\%20without\%20pub-

lic\%20money.pdf> accessed 20 August 2017, for a more optimistic view that considers bail-in constructive even in a systemic crisis Zhou et al. (n 15) 22.

${ }^{34}$ For the general idea that PSI (bail-in) is a pro-cyclical crisis accelerator, because haircuts chill investors and thus make it harder for struggling banks to refinance themselves, Avgouleas and Goodhart (n 15) 16. See also IV. 3.

${ }^{35}$ Sommer (n 12) 214, 222.

${ }^{36}$ On the critical importance of central bank liquidity assistance, Thomas Philippon and Aude Salord, Bail-in and Bank Resolution in Europe (International Center for Monetary and Banking Studies 2017) 48; on restrictions that might result from a lack of central bank eligible collateral, Avgouleas and Goodhart (n 15$) 17$.

${ }^{37}$ For the seminal model see Douglas W. Diamond and Philip H. Dybvig, 'Bank Runs, Deposit Insurance, and Liquidity', (1983) 91 JPE 401. For an extension that shows that modern bank runs do not only occur at deposit-taking credit institutions but also at similarly financed commercial and investment banks see Gary Gorton, 'The Panic of 2007' in Federal Reserve Bank of Kansas City (ed), Maintaining Stability in a Changing Financial System (Federal Reserve of Kansas City, 2009) 131, 199-231; Gary Gorton, 'Information, Liquidity, and the (Ongoing) Panic of 2007', (2009) 99 AER Papers \& Proceedings 567-72. 
occur at other, similarly situated institutions. ${ }^{38}$ Only this induces investors in runnable debt to wait-out the crisis. The first line of defense against investor panic obviously is the prescription of a sufficiently large layer of long-term (non-runnable), high-quality, and easy to bail-in capital that assures other creditors that PSI will not reach their claims. ${ }^{39}$ Ultimately, however, with bounded rationality and the scope of the crisis unclear, the existence of a second bulwark is even more important. Only if a credible government backstop is in place for situations in which the predestined cushion for bail-in is insufficient, will other claimholders refrain from withdrawing their funds. Counter to the immediate intuition, PSI thus requires a strong backstop for all runnable positions on the liability side of banks' balance sheet, absent which it accelerates ensuing crises. ${ }^{40}$

\section{Key desiderata for an efficient bail-in regime}

The objective of the bail-in tool to induce adequate pricing of the risk of bank failure by all investors who provide capital determines the preconditions under which a regulatory intervention can lead to efficient outcomes. The key desideratum is that - at least - sophisticated investors must be capable to price the risk adequately which requires a reasonably certain ex ante designation of the risk borne by investors. More specifically, a well-designed bail-in instrument needs to define a clear-cut, difficult to game trigger event (e.g. Common Equity Tier 1-ratio), has to make bail-inable capital instruments identifiable and must allow predicting the particular consequences of the implementation of the tool (e.g haircuts/conversions occur automatically without discretion $)^{41}$ in order to allow for an assessment of default probabilities, exposure at default and loss given default that is not additionally blurred by legal uncertainty. ${ }^{42}$ This statement does not disregard that commentators have argued in favor of a discretionary implementation of resolution tools according to a strategy devised on a case-by-case basis by

38 See Avgouleas and Goodhart (n 15) 11 pointing to the experience reported in Timothy F. Geithner, Stress Test: Reflections on Financial Crises (Random House, 2014) 306.

${ }^{39}$ In principle, a sufficiently upholstered, comforting capital cushion could prevent more senior claimants of all sorts from running and thus prevent contagion that would otherwise loom, see Stefano Micossi, Ginevra Bruzzone, and Miriam Cassella, 'Bail-in Provisions in State Aid and Resolution Procedures: Are they consistent with systemic stability' (2014) Centre for European Policy Studies (CEPS) Policy Brief N. 318, 9 <https://www.ceps.eu/system/files/PB\%20318\%20SM\%20et\%20al\%20Bail-in\%20Provi-

sions\%20in\%20State\%20Aid\%20and\%20Resolution\%20Procedures\%20final_0.pdf> accessed 20 August 2017; Avgouleas and Goodhart (n 15) 17-18.

${ }^{40}$ It is yet another question, how far these backstops should reach to achieve the stability objective in a world, in which large and critical parts of the financial system consist of non-bank (shadow) banks. See for instance, the far-reaching policy recommendation in Gary Gorton, Slapped by the Invisible Hand (OUP 2010) (recommending government guarantees for senior tranches of securitizations of approved asset classes).

41 Jan Pieter Krahnen and Laura Morretti, 'Bail-In Clauses' in Esther Faia, Andreas Hackethal, Michalis Halliassos, Katja Langenbucher (eds), Financial Regulation (CUP 2015) 136-142; John Armour, 'Making Bank Resolution Credible' (2014) European Corporate Governance Institute (ECGI) Law Working Paper 244/2014, 20-21 <http://ssrn.com/abstract=2393998> accessed 20 August 2017; Huertas (n 21) 173. The Liikanen-Report contains a condensed view of the issue, cf. High-level Expert Group on reforming the structure of the EU banking sector, Final Report (2012) 103-104 <http://ec.europa.eu/finance/bank/docs/high-level_expert_group/report_en.pdf> accessed 20 August 2017.

${ }^{42}$ On the importance of legal certainty as a precondition for the credibility of the system particularly in cross-border contexts see Philippon and Salord (n 36) 42. Only if actual default probabilities and losses diverge materially from ex ante expectations will investors in financial instruments subject to bail-in be chilled by haircuts and stop funding other banks. If investors can instead gauge and price default probabilities and consequences correctly, actual bail-ins should not have the pro-cyclical effects feared by some commentators ( $n$ 34) but only reflect worsened overall economic conditions which should be tackled by monetary policy. For the different stance in systemic crises see II. 2 . 
an empowered resolution authority, ${ }^{43}$ but shows the inherent tension between the emphasis on ex post-efficient outcomes and the inefficient ex ante effects of uncertainty which-in extremis-may compromise the statutory bail-in tool as an adequate mechanism for PSI in toto. ${ }^{44}$ Where policy makers opt for bail-in nevertheless, the discretionary elements in the resolution framework that impact on the predictability of PSI should at least be limited to the indispensable.

Once implemented, the bail-in instrument must not destabilize markets. In order to prevent knock-on effects, the bail-inable instruments have to be held outside the banking sector by investors with sufficient loss-bearing capacity (e.g. insurance companies, pension funds, high-net-worth individuals, hedge-funds). ${ }^{45}$

Under these conditions, a bank failure may become a non-disruptive event that does not imperil market participants' trust in the financial sector. Banks' reorganizations potentially become akin to those of airlines that can today fly "out of chapter 11" without jeopardizing customer confidence.

\section{IV.Abundant regulatory discretion under the BRRD-regime}

The bail-in tool as provided in the BRRD and SRM-Reg hardly lives-up to the ideal just outlined. In fact, the regulatory framework for PSI in the EU is highly complicated with a multitude of exceptions, counter-exceptions and restrictions that require discretionary choices by many authorities that may be subject to political bullying. The publicly enforced regime of an ad hoc bail-in complicates the prediction of outcomes, not least because its proper functioning depends critically on close inter-agency cooperation and information sharing across jurisdictions. In sum, the intricacies and ambiguities enshrined in the regulatory framework will impair the implementation of PSI's main policy objective in a way that leads to the gloomy conclusion that the bail-in tool under the BRRD and the SRM-Reg is likely to fail.

To be sure, the steady state under the new regime may be better than the one characterized by abundant government guarantees and bail-outs. Yet, the only improvement arguably follows from investors' unspecific perception that bank debt has become somewhat more risky. Yet, a more precise assessment of the risks involved in the investment in an individual institutions' capital is severely impeded by the wide array of outcomes conceivable under the BRRD. Market participants have to predict a multitude of decisions that public authorities have to make immediately before or in resolution. If they err, risk premiums will be distorted and the market discipline emanating from them may in fact set wrong incentives. Moreover, sudden information revelations about the actual riskiness of bank debt remain plausible, with the undesirable consequences of abrupt adjustments across markets. ${ }^{46}$

${ }^{43}$ Zhou et al. (n 15) 10-11 who nevertheless acknowledge the importance "to minimize the uncertainty generated by a discretionary use of bail-in power and to avoid surprising market participants".

${ }^{44}$ For the radical view, based on similar considerations, that any non-equity loss-absorbing capital is inferior to the prescription of more equity see Anat Admati and Martin Hellwig, The Bankers' New Clothes (Princeton University Press 2013), 187-8.

45 Zhou et al. (n 15) 22; Krahnen and Morretti (n 41) 140; Tröger (n 22) 589; Martin R. Götz and Tobias H. Tröger, 'Should the Marketing of Subordinated Debt Be Ristricted/Different in One Way or the Other? What to Do in the Case of Mis-selling?' In-Depth Analysis for the Economics and Monetary Affairs Committee of the European Parliament (2016), $6 \quad$ <http://www.europarl.europa.eu/RegData/etudes/IDAN/2016/497723/IPOL_IDA(2016)497723_EN.pdf> accessed 20 August 2017. See also infra IV. 3.

${ }^{46}$ See Gary Gorton, 'The Panic of 2007', in The Federal Reserve Bank of Kansas City (ed) Maintaining Stability in a Changing Financial System (Federal Reserve Bank of Kansas City 2009) 131, 199-231 (showing that the Lehman collapse led to a panic caused by a sudden information revelation); Gary Gorton, 'Information, Liquidity, and the (Ongoing) Panic of 2007', (2009) 99 AER Papers \& Proceedings 567-72; see also Enrico Perrotti, 'The Roots of Shadow Banking' (2013) Center for Economic Policy Research (CEPR) Policy Insight No. 69, 3 
This becomes clear when the general preconditions for any PSI through the application of the bail-in tool (infra IV. 1) and the details of its implementation (infra IV. 2) are scrutinized. Finally, some of the uncertainties that surround PSI are also linked to the observation, that the BRRD restricts the holding of bail-in capital insufficiently: If bail-in capital is held by investors who actually do not possess the required loss bearing-capacity, this will increase the likelihood of bail-outs and thus compromise the credibility of the regime ex ante (infra IV. 3).

\section{Precondition for PSI: resolution}

The primary precondition for the application of the bail-in tool is that supervisory or resolution authorities trigger formal resolution proceedings for an institution. ${ }^{47}$ The law lays down three factors that have to be assessed: the institution put in resolution has to be failing or is likely to fail in the future (infra a)), there is no prospect of any alternative private or public measure to avert failure (infra b)), and resolution serves the public interest better than ordinary insolvency proceedings (infra c)). The interpretation of each criterion requires supervisory and/or resolution authorities to substantiate relatively open standards which hampers the prediction of outcomes absent a well-established administrative practice. Therefore, the regulatory framework itself gives little reason to believe that forbearance is reduced as a function of more stringent regulation. ${ }^{48}$ By nature, enhanced certainty can only be accomplished over time. However, reaching this state will prove particularly difficult in the EU due to an overlap of competences and a lack of transparency of no-action decisions (infra d)).

\section{a) Institution is failing or likely to fail}

The primary determination is whether an institution is failing or likely to fail, where the BRRD provides for specifications under which circumstances such an assessment is justified. ${ }^{49}$ Besides the classical triggers for insolvency-over-indebtedness (accounting or balance-sheet insolvency) and illiquidity (technical or cash-flow insolvency) $)^{50}$-the law stipulates that failure occurs if violations of prudential banking regulation (particularly of own funds requirements) warrant the withdrawal of the institution's authorization ${ }^{51}$ or extraordinary public support is needed..$^{52}$ Particularly where the relevant determinations involve a prognosis for the "near future", knowledge about the applied methodology, the factual basis (data) taken as starting point for the projection etc. become key. Even with regard to the well-established concepts of balance-sheet and cash-flow insolvency, some uncertainty remains as the interpretation of EU law cannot immediately draw on doctrine and concepts developed in Member

$<$ www.cepr.org/sites/default/files/news/Policylnsight69.pdf> (describing how increased margins thwarted refinancing plans and led to fire-sales of special purpose vehicles that held collateralized debt obligations).

${ }^{47}$ According to BRRD art. 1(1)(a) and recital 1 the regime applies to credit institutions, BRRD art. 2(2), and investment firms, BRRD art. 2(3), as defined in Regulation (EU) No 575/2013 of the European Parliament and of the Council of 26 June 2013 on prudential requirements for credit institutions and investment firms and amending Regulation (EU) No 648/2012, art. 4(1)(1) and (2), [2013] OJ L176/1.

${ }^{48}$ For a skeptical view on this hope frequently associated with the introduction of PSI see Avgouleas and Goodhart (n 15) 3, 11 (pointing to the incentive to delay intervention as a result of higher legal risks when losses are imposed on bank creditors, which is not present in bail-out scenarios).

${ }^{49}$ BRRD art. 32(1)(a), (4). For an overview see Danny Busch, 'Governance of the Single Resolution Mechanism' in Danny Busch and Guido Ferrarini (eds.) European Banking Union (OUP 2015) para 9.101; Wojcik (n 21) 98-99; Binder (n 23) paras 2.38-2.46.

${ }^{50}$ BRRD art. 32(4)(1)(b) and (c). The insolvency-related triggers have the advantage that they allow bailin at a stage when investors' property rights do not pose a significant impediment to PSI, yet kick-in too late for restoring the institution's viability, see Zhou et al. (n 15) 11. On the specific valuation problems in the banking sector Anna Gardella, 'Bail-in and the Financing of Resolution within the SRM Framework' in Danny Busch and Guido Ferrarini (eds.) European Banking Union (OUP 2015) para 11.53.

${ }^{51}$ BRRD art. 32(4)(1)(a).

${ }^{52}$ BRRD art. 32(4)(1)(d). 
States' insolvency laws. ${ }^{53}$ Quite importantly, the European framework does not condition resolution on any quantitative thresholds like, for instance, capital adequacy ratios $50 \%$ or $75 \%$ below the norm. ${ }^{54}$

The difficulties become even more pronounced once the exception to the general principle that government support automatically triggers resolution with mandatory and significant PSI ${ }^{55}$ is taken into account. ${ }^{56}$ In fact, the systemic exception stipulated in the BRRD tries no less than squaring the circle: on the one hand it requires that the public backing of ailing institutions is extended to avert a systemic event while on the other hand the measures have to be of precautionary and temporary nature for otherwise safe and sound institutions. More specifically, any form of permissible government support ${ }^{57}$ has to be provided "in order to remedy a serious disturbance in the economy of a Member State and preserve financial stability" ${ }^{\prime 28}$ but is confined to solvent institutions and is not supposed to offset losses the institution has incurred or is likely to incur in the near future. ${ }^{59}$ Instead, precautionary recapitalizations are only allowed to cover capital shortfalls revealed in hypothetical adverse scenarios used in European or national stress tests. ${ }^{60}$ Hence, the exception requires to assess the systemic ramifications of a hypothetical failure of an institution that is actually remote from crisis (but flunked in a stress test) ${ }^{61}$ and a flawless going-concern (but cannot address markets to shore-up its capital basis). It is clear that the exception is limited to completely extraordinary exogenous shocks to SIFIs, unless the restrictive criteria for public bail-outs without minimum PSI are softened in the supervisory and resolution practice. ${ }^{62}$ In the latter scenario, far-reaching government guarantees would remain customary to a significant degree and hence the perils arising from inadequate pricing

${ }^{53}$ See generally for the European Court of Justice' autonomous interpretation of EU secondary law Case C 582/15 van Vemde [2017] ECR I-nma, para 25; Case C 294/16 J.Z. [2017] ECR I-man, para 35; Case C 108/16 Dworzecki [2016] ECR I-mn, para 28; Case C 66/08 Kozłowski [2008] ECR I-6041, para 42.

${ }^{54}$ For such a proposal Zhou et al. (n 15) 11. For the rationale for such clear-cut triggers see III.

55 In resolution, BRRD arts. 56(1), 37(10)(a) prescribe that at least $8 \%$ of an institution's total liabilities are bailed-in before any government support in the form of a capital contribution or even the nationalization of the bank can be extended under BRRD arts. 57, 58; similarly, BRRD art. 45(5) requires a minimum bail-in of the same proportion before resolution financing arrangements can take any losses. See generally Tröger (n 22 ) 590.

${ }^{56}$ The second part of BRRD art. 32(4)(1)(d) qualifies the general rule that if an institution requires public support it is failing or likely to fail.

57 The government can guarantee the repayment of central bank emergency liquidity assistance or of newly issued liabilities and can also provide own funds or purchase capital instruments, BRRD art. 32(4)(1)(d)(i)(iii).

${ }^{58}$ BRRD art. 32(4)(1). On this precondition see also Gardella (n 50) para 11.09.

${ }^{59}$ BRRD art. 32(4)(2).

60 BRRD art. 32(4)(3).

61 It is important that the typical methodolgy used in stress tests, regardless of political preferences, creates a bias with regard to the pre-conditions for a precautionary recapitalization, Philippon and Salord (n 36) 43-44. The reason is that the baseline scenario represents a statistical forecast (median), which implies that worse developments occur with $50 \%$ probability. Hence, passing under baseline conditions (and failing under more or less heavy stress) does not necessarily indicate that a sound bank experiences problems under exceptional circumstances.

62 The first case of a precautionary recapitalization under the new rules raises some doubts as to the pungency of the enforcement practices authorities will follow, because there is no reproducible indication that the pertinent bank's failure, which was looming for many months, would have caused a systemic event, on the facts of the government intervention see European Commission, 'State aid: Commission authorises precautionary recapitalisation of Italian bank Monte dei Paschi di Siena' (2017) < http://europa.eu/rapid/press-release_IP17-1905_en.pdf> accessed 20 August 2017. 
of bank capital would persist (see II.1). In that case, the main policy objective pursued with the introduction of the bail-in tool would be missed. ${ }^{63}$

From the perspective of an investor who seeks to gauge the risk inherent in an investment in a bank's capital instruments subject to bail-in it is primarily important to understand for which institutions government support without minimum PSI is available. For that purpose, investors have to comprehend when a bank's failure is considered to trigger a systemic event within the meaning of the law. Given the rough criteria put forward in Art. 6(4) of the SSM Regulation ${ }^{64}$ it cannot be extrapolated from the designation of a bank as "significant" for supervisory purposes within the SSM ${ }^{65}$ that its failure would automatically lead to a "serious disturbance in the economy of a Member State" and jeopardize financial stability. In light of the policy rationale that underpins art. 32(4)(1), a more granular and individual prognosis is needed that looks at the banks individual position within the Member State's, European or global economy. To limit the political element and guarantee for a maximum of time-consistency in the relevant determinations, they should be based on hard economic evidence and derived from methodologically comprehensible, data-based projections. Even then, market participants will not always be able to precisely predict outcomes because supervisory and resolution authorities will typically possess information that is unavailable to investors due to the well-known opaqueness of banks. ${ }^{66}$ Yet, with the seasoned input from specialized information intermediaries, the ex ante-assessments would approximate the true figures for the default probability, exposure at default and loss given default. At any rate, even an imperfect system would be far more desirable than an alternative where the rigid limits set for government interventions without minimum PSI would be weakened. Pricing of bank capital once again hinged on forecasts of politically driven bail-out decisions and market discipline remained compromised.

b) No prospect to prevent failure

Art. 32(1)(b) of the BRRD further requires that, before resolution is triggered, all options for private sector solutions ${ }^{67}$ or supervisory interventions are explored but do not offer the prospect to avoid the institution's failure. Clearly, determining the probabilities of a reorganization to prevent bankruptcy is part of the general appraisal of default risks investors have to conduct. In this regard, the BRRD does not introduce a discrete form of insecurity beyond the unavoidable. Yet, it alters the equation at least

${ }^{63}$ See also Martin R. Götz, Jan Pieter Krahnen, Tobias H. Tröger, 'Taking Bail-in Seriously - The Looming Risks for Banking Policy in the Rescue of Monte Paschi di Siena' (2017) SAFE Policy Letter No. $54<$ http://safefrankfurt.de/fileadmin/user_upload/editor_common/Policy_Center/SAFE_Policy_Letter_54.pdf> accessed 20 August 2017; Binder (n 23) paras 2.41, 2.42 admits a rather unclear character of the statutory preconditions but considers this as a "rather technical" aspect.

${ }^{64}$ Council Regulation (EU) No 1024/2013 of 15 October 2013 conferring specific tasks on the European Central Bank concerning policies relating to the prudential supervision of credit institutions [2013] OJ L 287/63.

${ }^{65}$ For a detailed description of the relevant criteria see Klaus Lackhoff, 'Which Credit Institutions Will Be Supervised by the Single Supervisory Mechanism?' [2013] 28 J.I.B.L.R. 454; Gianni Lo Schiavo, 'From National Banking Supervision to a Centralized Model of Prudential Supervision in Europe' [2014] 21 MJ 110, 126-30, 1312; for a brief overview Tobias H. Tröger, 'The Single Supervisory Mechanism - Panacea or Quack Banking Regulation' [2014] 15 EBOR 449, 467.

${ }^{66}$ On the general observation that impedes debt-governance in the first place Donald P. Morgan, 'Rating banks: Risk and uncertainty in an opaque industry' (2002) 92 Am.Econ.Rev. 874-888.

${ }^{67}$ Actions taken by an Institutional Protection Schemes (IPS), common among public sector banks for instance in Germany and Austria, are considered as private sector measures although they involve the transfer of funds or the provision of support from public entities and thus could be characterized as government support, see BRRD art. 32(1)(b) (explicitly characterizing measures by IPS as private sector measures). This can be justified on the ground that IPS do not burden public finances beyond the means already devoted to the state-owned banking groups. 
slightly, because it is not the actual availability of reorganization options that is relevant but the involved authorities' perception of it.

Matters are truly complicated, however, by the second prong of the quest for alternatives to resolution: where supervisory action is possible, once again, information on the authorities' stance becomes key. For instance, a write down or a conversion of own funds under Art. 59(2) of the BRRD will typically be possible. Whether such limited $\mathrm{PSI}^{68}$ suffices to avoid the failure of the troubled institution depends critically on the methodology resolution authorities employ to determine whether the strengthened regulatory capital base re-establishes the institution's viability, in particular if it creates sufficient trust in the institution's medium-term survival. Therefore, prognostic problems similar to those under art. 46(2) of the BRRD arise. ${ }^{69}$ Yet, for investors who do not hold AT1 or T2 instruments, the insecurity is more momentous at this stage. As long as a write down or conversion fully revamps the institution, they do not have to contribute to the reorganization and thus do not incur any losses. They only become liable in a comprehensive PSI if writing down or converting own funds does not suffice to avoid the institution's failure.

\section{c) Resolution required in the public interest}

Finally, resolution may only be triggered if the objectives laid down in art. 31(2) of the BRRD can solely be achieved in a proportionate manner outside regular insolvency proceedings. ${ }^{70}$ In contrast to insolvency proceedings for commercial firms that seek to maximize the bankrupt firm's value und to minimize the losses of its creditors, the special resolution framework for financial firms aims at preserving financial stability through the continuation of the critical functions of the failing institution. ${ }^{71}$ The relevant resolution goals mirror the general observation that banks are special due to their role as liquidity providers for the economy and carriers of the payment system, ${ }^{72}$ which warrants a specific regulatory treatment also in case of failure. In other words, where an entity or group that is classified as an 'institution' that falls under the remit of the BRRD ${ }^{73}$ due to its small size or idiosyncratic (non-interconnected) business model does not exhibit the distinct properties that separate banks from other corporate entities, it can be exempt from resolution in case of failure and wound-down in regular insolvency proceedings. ${ }^{74}$ Once again, a projection of the troubled institution's failure that seeks to predict the impact on a Member State's, the EU or the global economy is needed and raises exactly the same uncertainties discussed before (see IV. 1. a)). ${ }^{75}$

68 The powers referred to in art. 59(2) of the BRRD apply to "relevant capital instruments" which are defined as Additional Tier 1 (AT1) and Tier 2 (T2) instruments in art. 2(1)(74) of the BRRD.

${ }^{69}$ On these see infra IV. 2. d) (1).

${ }^{70}$ BRRD, art. 32(1)(c), (5). On the policy rationale see Wojcik (n 21) 100.

${ }^{71}$ BRRD, art. 31(2)(a) and (b); for a detailed description of resolution objectives see Binder (n 23) paras. 2.26-2.37.

72 For a detailed description of banks' pivotal macro-economic function for the economy under neoKeynesian assumptions see Tobias H. Tröger, 'How Special Are They? Targeting systemic risk by regulating shadow banking' in Bertram Lomfeld, Alessandro Somma, and Peer Zumbansen (eds.), Reshaping Markets (CUP 2016) 185, 191-193.

73 See BRRD arts. 1(1) and 2(1)(23).

74 This relatively high-stake for the initiation of resolution proceedings under the BRRD prevents testing the resolution regime in low-profile cases which would yield experience and ultimately confidence of market participants in the proper functioning of the regime, see Sommer ( $n$ 12) 224. On a rationale for a restrictive approach that pertains to an allegedly higher standard of protection for property rights in regular insolvency proceedings see Binder (n 23) para 2.39.

${ }^{75}$ Binder (n 23) paras. 2.45 and 2.46 acknowledges the difficulties of making the relevant assessment under time pressure and thus interprets the rule as a procedural requirement to make an "educated guess". The U.S. regime requires the same determination, DFA, § 203(a)(2)(F), § 12 U.S.C. § 5383(a)(2)(F) but complicates 
To be sure, the difficulties associated with forecasting outcomes were less relevant from an investor's perspective if PSI would also occur in regular insolvency proceedings. However, the recent experience in Italy indicates, ${ }^{76}$ that bail-out-avid politicians can exploit the exception to avoid inflicting losses on investors and stabilize failing banks with government money instead; EU state-aid rules provide only a lax restriction in this regard. ${ }^{77}$ In other words, at the margin, the determination may relieve holders of bank capital from PSI and thus alter their risk determination significantly. This is particularly true if the greater leeway to extend state aid in regular insolvency proceedings, in which minimum PSI is not rigidly required, is considered already ex ante in the relevant determinations under BRRD, art. $32(1)(c)$.

\section{d) Competence to determine conditions for resolution}

Investors will base their risk assessment on the competent authorities' administrative practice. The accuracy of any prediction of PSI thus hinges on understanding who makes the final call under which circumstances. Regrettably, the BRRD and SRM-Regulation establish a multipolar decision making structure that further impedes predictability. ${ }^{78}$ Under the BRRD supervisory authorities ${ }^{79}$ determine whether an institution is failing or likely to fail, ${ }^{80}$ because they possess the necessary information as a result of their ongoing oversight, supervisory exams etc. Member States can, however, also task resolution authorities with the relevant determination if the latter are in a position to assess the situation,

matters for investors even further because the relevant decision makers also have to take distributive consequences of a default into account, see DFA, § 203(a)(2)(C), § 12 U.S.C. § 5383(a)(2)(C).

${ }^{76}$ In June 2017 the Italian government injected $€ 17$ bill into Veneto Banca and Banca Populare di Vicenza and thus protected senior bond-holders in full, the junior claims being held by a government orchestrated rescue fund already, see Deborah Ball, 'Italy to Spend Up to \$19 Billion to Bail Out Two Banks' Wall Street Journal (New York, 25 June 2017) <https://www.wsj.com/articles/italy-is-prepared-to-spend-billions-in-shutdown-of-twobanks-1498418669> accessed 20 August 2017; Editorial, 'Bank Bail-Outs Italian Style' Wall Street Journal (New York, 26 June 2017) < https://www.wsj.com/articles/bank-bailouts-italian-style-1498517158 > accessed 20 August 2017; Rachel Sanderson et al., 'Italy sets aside €17bn to wind down failing lenders' Financial Times (London, 26 June 2017) <https://www.ft.com/content/83ad52a8-59a5-11e7-9bc8-8055f264aa8b > accessed 20 August 2017.

${ }^{77}$ For the view in the daily press that regular insolvency proceedings were favored in order to avoid full PSI in resolution see Simon Nixon, 'Deal on Italian Banks Raises Questions About Eurozone Rules' Wall Street Journal (New York, 25 June 2017) <https://www.wsj.com/articles/deal-on-italian-banks-raises-questions-abouteurozone-rules-1498407926> accessed 20 August 2017; Paul J. Davies, 'Why Italy's Bank Rescue Looks a Backward Step for Europe' Wall Street Journal (New York, 25 June 2017) <https://www.wsj.com/articles/why-italysbank-rescue-looks-a-backward-step-for-europe-1498479633> accessed 20 August 2017; Editorial, 'Italy shows EU banking union still has far to go' Financial Times (London, 26 June 2017) <https://www.ft.com/content/f01db25e-5a70-11e7-9bc8-8055f264aa8b> accessed 20 August 2017; Lucrezia Reichlin, 'The European banking union falls short in Italy' Financial Times (London, 26 June 2017) <https://www.ft.com/content/3b8bc570-5a7e-11e7-b553-e2df1b0c3220> accessed 20 August 2017.

${ }^{78}$ See also Binder (n 23) para 2.42; Philippon and Salord (n 36) 47. In the US, the decision is taken by the Secretary of the Treasury, however on the basis of a recommendation of the FDIC and the Board of Governors of the Federal Reserve System, DFA, § 203(a)(1)(A), § 12 U.S.C. § 5383(a)(1)(A).

79 In the context of the SSM this can be either the ECB with regard to significant banks or the national supervisor in the Member State, see art. 4(1)(40) of Regulation (EU) No 575/2013 of the European Parliament and of the Council of 26 June 2013 on prudential requirements for credit institutions and investment firms and amending Regulation (EU) No 648/2012, [2013] OJ L176/1 [hereinafter: CRR] and arts. 4(1), 6 of Council Regulation (EU) No 1024/2013 of 15 October 2013 conferring specific tasks on the European Central Bank concerning policies relating to the prudential supervision of credit institutions, [2013] OJ L 287/63 [hereinafter: SSM Regulation].

${ }^{80}$ BRRD arts. 32(1)(a), 2(1)(21). 
in particular have access to all material information. ${ }^{81}$ Where Member States use the option, simultaneous competences arise, requiring investors to study the administrative practice of at least two authorities and determine who's more "trigger happy“. Even within the SRM where a hierarchy is established that gives the Single Resolution Board (SRB) ${ }^{82}$ the ultimate decision making power, ${ }^{83}$ a delay due to a ping-pong between regulators with diverging preferences for resolution ${ }^{84}$ may ensue. ${ }^{85}$

The potentially most important exemption from mandatory minimum PSI under art. 32(4)(d) of the BRRD (see IV. 1. a)) vests veto power with another important player. The European Commission has to approve government support that is provided to avert a systemic event under the Union State aid framework. ${ }^{86}$ This requirement adds another layer of forecasting uncertainty to the already substantial difficulties in assessing the timing and the impact of a bank's resolution that are important determinants for default probability and loss given default.

\section{Application of bail-in tool after triggering resolution}

The uncertainties surrounding mandatory PSI as a result of a bail-in become amplified if the nitty-gritty of the application of the tool under the BRRD is analyzed in more detail. Discretionary decisions of resolution authorities that can lead to widely diverging outcomes concern, with due variation, the selection of the bail-in tool from the resolution tool-box (IV. 2. a)), the choice of specific consequences of a bail-in (IV. 2. b)), the exemptions of certain liabilities from bail-in (IV. 2. c)), and the general limits on PSI (IV. 2. d)). Finally, a good deal of the uncertainty surrounding the prediction of the result of PSI from an investor's perspective is exacerbated where resolution authorities face the failure of a complex corporate structure, particularly where operations of the banking group stretch across borders (IV. 2. e)).

${ }^{81}$ BRRD art. 32(2).

82 The SRB was established as a Union agency with legal personality and is supposed to administer and coordinate resolution in the Banking Union, see BRRD art. 42(1).

${ }^{83}$ See SRM-Reg art. 18(1)(2).

${ }^{84}$ Failure can be regarded as a sign for deficiencies in the ongoing prudential supervision of banks. In this scenario supervisors have an incentive to delay resolution to camouflage their own shortcomings, see eg Jean Pisani-Ferri et al., 'What Kind of a European Banking Union' (2012) Bruegel Policy Contribution No. 12, 11 <http://bruegel.org/wp-content/uploads/imported/publications/pc_2012_12_Banking.pdf>; Rishi Goyal et al., 'A Banking Union for the Euro Area', (2013) International Monetary Fund Staff Discussion Note 13/01, 14 <http://www.imf.org/ /media/Websites/IMF/imported-full-text-pdf/external/pubs/ft/sdn/2013/_sdn1301.ashx> accessed 20 August 2017.

${ }^{85}$ For a similar critique of the overlapping competences, Marco Pagano, 'Lessons from the European financial crisis' in Esther Faia, Andreas Hackethal, Michalis Halliassos, Katja Langenbucher (eds), Financial Regulation (CUP 2015) 23, 40.

${ }^{86}$ BRRD art. 32(4)(2). 


\section{a) Selection from resolution tools}

Once resolution has been triggered, no automatic bail-in occurs. Instead resolution authorities choose at their discretion from a set of resolution tools ${ }^{87}$ the ones that are best apt to implement the resolution strategy devised for the individual institution. ${ }^{88}$ Hence, even in resolution PSI may be avoided if resolution authorities opt to manage the crisis by either selling the institution's business, or transferring it to a bridge institution, or separating specific (troubled) assets. ${ }^{89}$ The only prescription of the BRRD is that if the resolution strategy chosen will lead to debtholder involvement, AT1 and T2-instruments have to be written-down or converted immediately in accordance with art. 59(2) of the BRRD, regardless of when the bail-in tool is applied..$^{90}$ As a consequence, and not too surprisingly, investors in own funds - who are written-off or converted also outside of resolution if the institution or an affiliate that uses the respective capital instruments to fulfill own funds-requirements reach the point of non viability (PONV) ${ }^{91}$-are first in line when it comes to $\mathrm{PSI},{ }^{92}$ yet, even their contribution in resolution is not certain as a matter of law, if resolution authorities manage the crisis without imposing losses on the troubled bank's creditors.

Resolution authorities are vested with a broad range of resolution powers that allow the granular implementation of the chosen resolution strategy as deemed expedient. ${ }^{93}$

Hence, investors who seek to anticipate the outcomes of resolution face a wide array of discretionary choices both on the fundamental (selection of resolution strategy and tools) and on the implementation (execution of resolution powers) level. The prediction is even more complicated within the SRM because, once again, the regime only partly supranationalizes the relevant decisions. The SRB is exclusively in charge for stand-alone entities and groups, which are directly supervised by the ECB and cross-border groups. ${ }^{94}$ Yet even for the institutions that come under its remit, Member States' resolution authorities are in charge of the implementation of the SRB-devised strategy vis-à-vis failed institutions. ${ }^{95}$ For all other institutions Member States' resolution authorities ${ }^{96}$ generally decide on the resolution strategy, the application of resolution tools and the execution of resolution powers,

${ }^{87}$ BRRD art. 37(3) list the sale of business tool (BRRD arts. 38, 39), the bridge institution tool (BRRD arts. 40,41 ), the asset separation tool (BRRD art. 42), and the bail-in tool (BRRD art. 43, 44); for an overview see Christos Gortsos, 'The two main pillars of the European Banking Union: the legal framework in a nutshell' in: Jens Hinrich Binder and Christos Gortsos, The European Banking Union (2016) 17, 63; Busch (n 49) para 9.84-9.91. For the similarly equipped tool-box of the FDIC see DFA § 210(a)(1)(D), (F), (G), (M), , 12 U.S.C § 5390(a)(1) (D), (F), (G), (M).

${ }^{88}$ BRRD art. 37(4). The Federal Deposit Insurance Corporation (FDIC) which administers the special resolution regime created by the DFA also has broad discretionary powers in selecting resolution tools, DFA $\S$ 210(a)(1)(D), 12 U.S.C § 5390(a)(1)(D).

${ }^{89}$ See also Zhou et al. (n 15) 18-19 (discussing the advantages and downsides of specific resolution tools).

${ }^{90}$ BRRD, art. 37(2); for a detailed discussion Gardella (n 50) para 11.49.

${ }^{91}$ BRRD, art. 59(1)(a), (3)(b)-(d).

92 The same result is reached by Wojcik (n 21) 112 (arguing that the write-down and conversion tool has priority over the bail-in tool).

${ }^{93}$ See BRRD, arts. 63-71.

${ }^{94}$ SRM-Reg, art. 7(2).

${ }_{95}$ SRM-Reg, art. 29(1). Busch (n 49) para 9.09-9.14; Gortsos (n 87) 48-49; Wojcik (n 21 ) 102.

${ }^{96}$ Member States may choose to confer all resolution tasks with regard to its banking system to the SRB, SRM-Reg. art. 7(5). 
unless the Single Resolution Fund (SRF) ${ }^{97}$ is tapped to cover losses..$^{98}$ In the latter case, the SRB decides on the resolution scheme, that is, it determines the resolution strategy and the applicable resolution tools ${ }^{99}$ that have to be implemented by national resolution authorities using their resolution powers. At least in the latter case, outcomes may vary to a certain degree as a function of the leeway granted to national resolution authorities.

Once again, the vast scope of discretion the BRRD affords to authorities and the division of administrative competences impede a reliable projection of actual PSI in resolution.

\section{b) Selection of specific bail-in consequences}

Even after resolution was triggered and the application of the bail-in tool was determined, the specific consequences of PSI remain to some extent at the discretion of resolution authorities. ${ }^{100}$ Financial instruments can either be written-down or converted into equity. The bail-in tool allows for a comprehensive reorganization of the institution's balance sheet in reverse of the waterfall determined by the priority in insolvency ${ }^{101}$ More specifically, equity can be cancelled or transferred to bailed-in creditors, ${ }^{102}$ debt can be converted into equity. ${ }^{103}$ Liabilities can be written-down, ${ }^{104}$ their maturity and interest payments (amount, due date) can be amended or altered. ${ }^{105}$ Finally, debt instruments can be canceled, ${ }^{106}$ financial and derivative contracts can be closed-out and terminated. ${ }^{107}$ Sticking to the order of priority that applies in bankruptcy prevents that existing shareholders and junior creditors benefit from haircuts imposed upon senior creditors. ${ }^{108}$

The choice between the multiple options is determined by the immediate objectives of the bail-in tool which seeks to recapitalize the institution ${ }^{109}$ or to support the application of other resolution tools (for instance, to adequately capitalize a bridge institution, to facilitate a sale of business). ${ }^{110}$ Given that economic reasons may militate in favor of a burden-sharing between old and new equity-

97 The SRF was established by art. 67(1) of the SRM Reg. Its endowment was laid down in an intergovernmental agreement deliberately concluded by the Member States of the Banking Union outside the institutions of the EU which ensures that any future amendments require unanimous decisions, see Agreement on the transfer and mutualisation of contributions to the Single Resolution Fund, Council of the EU (2014) 8457.

98 SRM-Reg. art. 7(3).

${ }^{99}$ See SRM-Reg, art. 18(6).

100 Gardella (n 50) para 11.59, 11.61. It is unlikely that guidelines issued by the European Banking Authority (EBA) will become a game-changer as they do not eliminate the case-by-case, valuation-dependent specification of the selection procedure, see BRRD, art. 47(6) and EBA, Final Guidelines on the treatment of shareholders in bail-in or the write-down and conversion of capital instruments (2017) 6-11 <https://www.eba.europa.eu/documents/10180/1807527/Guidelines+on+the+treatment+of+shareholders+in+bail-in+\%28EBA-GL2017-04\%29.pdf/1eff0200-b5d8-4ca3-ace8-c6031e9a3928> accessed 20 August 2017.

${ }^{101}$ See BRRD art. 48(1); for more granular descriptions see Gardella (n 50) para 11.58; Wojcik (n 21) 111. For a similar predetermination of PSI in the US see DFA, § 210(b)(1), 12 U.S.C. § 5390(b)(1), which gives priority to government and employee claims that are largely exempt from bail-in under BRRD, art. 44(2)(g)(i) and (iii), see IV. 2. c) (1).

102 BRRD arts. 47(1)(a), 63(1)(h).

103 BRRD arts. 47(1)(b), 63(1)(f).

104 BRRD art. 63(1)(e).

105 BRRD art. 63(1)(j).

106 BRRD art. 63(1)(g).

107 BRRD art. 63(1)(k).

108 Zhou et al. (n 15) 13-14

${ }^{109}$ BRRD art. 43(2)(a).

${ }^{110}$ BRRD art. 43(2)(b). 
holders, ${ }^{111}$ even the extent to which bailed-in creditors participate in a potential upside of the resolved institution after bail-in remains unclear. Hence, once again knowledge about the resolution strategy and the methodology used by resolution authorities to forecast the success of resolution becomes important from the perspective of an investor who seeks to gauge the risk involved in a specific financial instrument. Hence, all the blurring uncertainty surrounding the respective predictions further weaken the market-discipline that emanates from PSI. A prediction becomes even more difficult if additional aspects that are, at best, loosely related to the resolution goals can legitimately be considered, like, for instance, the simplification of governance structures. ${ }^{112}$

\section{c) Liabilities exempt from bail-in}

As just discussed, the bail-in tool allows resolution authorities to re-engineer the whole liability side of a troubled institution's balance sheet. However, there are a number of positions that are either generally exempt from bail-in by law (infra IV. 2. c) (1)) or can be spared at the resolution authorities' discretion (infra IV. 2. c) (2)).

\section{(1) Exemptions by law}

The BRRD exempts several liabilities from bail-in (see Table 1). ${ }^{113}$

\begin{tabular}{|c|c|c|c|}
\hline $\begin{array}{l}\text { Protection of "vulner- } \\
\text { able" creditors (socio- } \\
\text { political exemption) }\end{array}$ & $\begin{array}{l}\text { Safeguarding financial } \\
\text { stability/prevention } \\
\text { of liquidity stress }\end{array}$ & $\begin{array}{l}\text { Guarantee of reliabil- } \\
\text { ity and legal certainty }\end{array}$ & $\begin{array}{l}\text { No indirect govern- } \\
\text { ment support }\end{array}$ \\
\hline 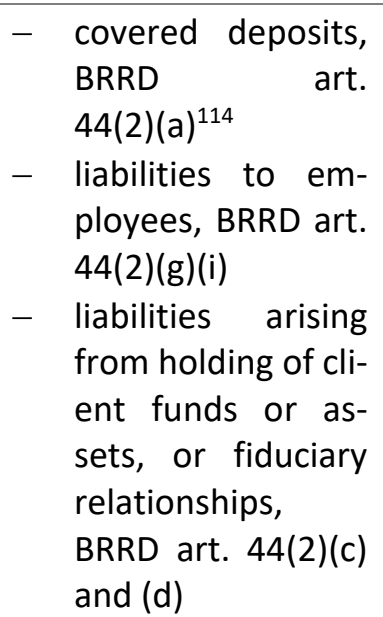 & $\begin{array}{l}\text { - claims of key mar- } \\
\text { ket participants, } \\
\text { service providers, } \\
\text { and backstop } \\
\text { mechanisms, } \\
\text { BRRD art. } 44(2)(\mathrm{e}), \\
\text { (f), (g)(ii) and (iv) } \\
\text { (for instance } \\
\text { shortdated liabili- } \\
\text { ties to other } \\
\text { banks) }\end{array}$ & 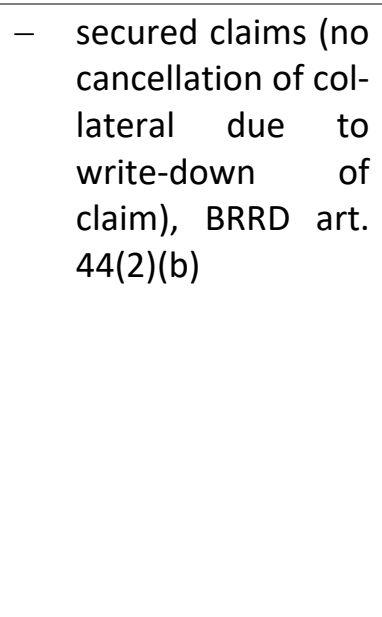 & $\begin{array}{l}\text { - Preferred claims of } \\
\text { tax and social se- } \\
\text { curity authorities, } \\
\text { BRRD art. } \\
44(2)(\mathrm{g})(\mathrm{iii})\end{array}$ \\
\hline
\end{tabular}

Table 1 - liabilities exempt from bail-in by law

Arguably, each of these exemptions can be justified as a matter of sound banking or public policy. ${ }^{115}$ However, their application generates problems because some of the terms used are rather vague and

111 Krahnen and Moretti ( $\mathrm{n}$ 41) 137; for a view common among lawyers that existing equity-holders should be precluded from any benefit from a future upswing of the failed institution, Gardella ( $\mathrm{n}$ 50) para 11.64.

112 Gardella (n 50) para 11.62.

${ }^{113}$ For detailed descriptions see Gardella (n 50) para 11.39; Wojcik (n 21) $108 \mathrm{f}$.

${ }^{114}$ The U.S.-resolution framework generally exempts deposit-taking institutions from Title 2 of the DoddFrank-Act and thus its bail-in regime, 12 U.S.C. $\S 1813(\mathrm{c})(2)$, and submits them to specific, FDIC-administered liquidation rules instead, see 12 U.S.C. $§ 5381(a)(8)(B)$.

115 See for instance Zhou et al. (n 15) 13 (discussing the rationale in favor of excluding certain types of senior unsecured debt from bail-in). Arguably, the case for exempting secured liabilities is rather weak, because it amplifies a general trend to resort to covered bonds which increases bail-in hostile asset encumbrance because bail-in increases the marginal cost of debt for banks that consequentially look for ways to lower their funding costs, see Zhou et al. (n 15) 21. The exemption of short-term interbank liabilities creates a bias in favor of ultrashort-term funding models that decrease resilience, Philippon and Salord (n 36) 50-51 
require an interpretation with a view to each and every institution's idiosyncratic business model, organizational structure etc. For instance, a contextualized specification is required to determine which goods or services "are critical to the daily functioning" of an institution's operations. ${ }^{116}$ The range of potential functions and thus exempt liabilities is particularly wide under the BRRD because it allows, in stark contrast to the US resolution regime, ${ }^{117}$ that the failing institution continues to operate after resolution. ${ }^{118}$

To be sure, the creditors that potentially benefit from this exemption might not be critical to the incentive-effect of PSI which seeks to influence those investors who finance the risk-taking and investment decisions of the bank (supra II. 1). Yet, these investors are indirectly affected by a broader or narrower construction of the underdetermined exemptions because the pool of liabilities available for PSI is either larger or smaller.

\section{(2) Exemptions at resolution authorities' discretion}

Furthermore, resolution authorities can exempt certain liabilities from bail-in if the resolution objectives would be missed otherwise (see Table 2). ${ }^{119}$

\begin{tabular}{l|l|l}
\hline $\begin{array}{l}\text { Ensuring the effective imple- } \\
\text { mentation of the resolution } \\
\text { strategy }\end{array}$ & Safeguarding financial stability & Avoiding destruction of value \\
\hline$-\begin{array}{l}\text { Practical impossibility of } \\
\text { timely bail-in, BRRD art. }\end{array}$ & $\begin{array}{l}\text { Continuity of critical func- } \\
\text { tions etc., BRRD art. }\end{array}$ & $\begin{array}{l}\text { Losses for other creditors } \\
\text { lower if certain liabilities } \\
44(3)(a)\end{array}$ \\
$\begin{array}{l}\text { are spared, BRRD art. } \\
-\begin{array}{l}\text { Prevention of contagion } \\
\text { (bank runs), BRRD art. } \\
44(3)(c)\end{array}\end{array}$ & $\begin{array}{l}44(3)(d) \\
\end{array}$ \\
\hline
\end{tabular}

Table 2 - liabilities exempt from bail-in at the resolution authority's discretion

Once again, the critical query from this paper's perspective is not whether the exceptions from bail-in, by and large, follow legitimate and comprehensible rationales. Instead, it is more important to understand that their application requires a specification of rather vague terms in individual contexts and thus conjures up yet another set of uncertainties that aggravates the prediction problems for investors. ${ }^{120}$ For instance, it will be very hard to forecast - at the time of investment - whether certain liability classes will be distributed in a way that their bail-in would lead to run-like scenarios ${ }^{121}$ or impede the continuity of critical functions of the troubled institution (see already IV. 2. c) (1)). In any case, it requires sufficient knowledge about the methodologies, data etc. used by resolution authorities in performing the relevant projections (see also IV. 1. a)).

116 See BRRD art. 44(2)(g)(ii).

117 On the narrow objective of resolution under Dodd-Frank (orderly liquidation) see n. 127.

118 The comparable US exemption, DFA, § 210(b)(4)(A)(ii), 12 U.S.C. § 5390(b)(4)(A)(ii) is thus more narrowly drawn because it only allows exemptions insofar as the orderly liquidation or the transfer of assets to a bridge company were thwarted by a bail-in, see in this respect the clarifying FDIC rule, § 12 C.F.R §380.270. However, on the other hand, the unfettered liquidation objective of the US resolution regime also entails a specific set of exemptions unparalleled in the E.U. that hinge on the goal to minimize creditor losses, see DFA, $\S$ 210(b)(4)(A)(i), (iii), and (iv), 12 U.S.C. §5390(b)(4)(A) (i), (iii), and (iv).

${ }^{119}$ For detailed descriptions see Gardella (n 50) para 11.40; Wojcik (n 21) 109.

${ }^{120}$ For a similar assessment Philippon and Salord (n 36) 52.

${ }^{121}$ For evidence from the financial crisis that contemporary bank-runs typically occur outside of deposittaking credit institutions in wholesale markets and are triggered by sudden information revelations regarding the (misperceived) risk-structure of certain asset classes see Gorton (n 40) 45-53. 
It is worth noting also at this stage that blurry predictions are not only relevant for those creditors who potentially benefit from the exemptions but also for those that are doubtlessly subject to bail-in: the typical consequence of granting an exemption is that the loss participation of other creditors increases. ${ }^{122}$ This is different only if the resolution financing mechanism or the SRF will assume the fraction of losses originally attributed to the exempt liabilities. ${ }^{123}$ Procedurally, such loss-taking contribution requires the consent of the European Commission because it has potentially distorting effects on competition. ${ }^{124}$ Hence, final outcomes once more hinge on the administrative practice of several authorities. As a consequence, for investors to gain a reasonable understanding of the actual risk involved in bail-in instruments, they would need all relevant information to forecast the relevant behavior.

\section{d) Limits of creditor participation}

The extent of PSI and thus the maximum loss participation is determined by the sum of liabilities that have to be subjected to bail-in to achieve the relevant resolution objectives (infra IV. 2. d) (1)). Furthermore, the resolution framework foresees that investors cannot be exposed to higher losses than they would incur in regular insolvency proceedings (infra IV. 2. d) (2)).

\section{(1) Valuation procedure for assets and liabilities}

The valuation of the resolved institution's assets and liabilities determines the maximum amount of PSI. ${ }^{125}$ After the application of the bail-in tool, the institution's balance sheet has to be agreed. ${ }^{126}$ If liquidation of the failing bank would not achieve the resolution goals, ${ }^{127}$ the (bridge) institution - after bail-in-has to fulfill the regulatory requirements for Common Equity Tier 1 (CET1), ${ }^{128}$ and this compli-

122 See BRRD art. 44(3) subpara 2. In its decision making process, the resolution authority has to account for this consequence, Gardella ( $n$ 50) para 11.40; Wojcik (n 21) 109. Generally on the trade-off to be made Emilios Avgouelas and Charles Goodhart, 'A Critical Evaluation of Bail-ins as Bank Recapitalization Mechanisms' in Franklin Allen, Elena Carletti, and Joanna Gray (eds.) Bearing the Losses from Bank and Sovereign Default in the Eurozone (Financial Institutions Center Press 2014) 65, 66.

${ }^{123}$ A contribution can be made only if the minimum PSI of $8 \%$ of total liabilities is met and can only amount to $5 \%$ of total liabilities, see BRRD art. 44(4); SRM Reg. art. 18(6). In the U.S., the Orderly Liquidation Fund is established to finance the liquidation responsibilities of the FDIC (costs of liquidation), DFA, § 210(n)(1), 12 U.S.C. $\S 5390(n)(1)$. Yet, by making authorized payments to existing creditors, see DFA § 210(b)(4), (d)(4), and (h)(5)(E), 12 U.S.C. $\S 5390(b)(4)$, (d)(4), and (h)(5)(E) the FDIC and thus the OLF can incur losses on similar grounds and to similar extends like the resolution financing mechanisms under the BRRD, despite the general principle of PSI (see $n$ 9).

${ }^{124}$ BRRD, art. 44(12), Gardella (n 50) para 11.41.

125 The legal framework for valuation is the same regardless of whether PSI occurs through write-down and conversion at the PONV (see IV. 2. b)) or through bail-in in resolution, see recital 81 of the BRRD; Gardella ( $\mathrm{n}$ 50) para 11.50 .

${ }^{126}$ This loss-absorption amount applies to all institutions regardless of the resolution strategy, see BRRD art. 46(1)(a). On the consequences for the calculation of Minimum Requirements for Own Funds and Eligible Liabilities (MREL), that will typically be at least as high as the prudential capital requirements (including macroprudential buffers and pillar II requirements) and mostly fulfilled with own funds capital instruments (CET1, AT1 and T2), World Bank, Understanding Bank Recovery and Resolution in the EU: A Guidebook to the BRRD (World Bank Group, 2016) 85-86.

127 On the key difference between the BRRD and the US resolution framework in this regard see $\mathrm{n} 7$.

${ }^{128}$ For this recapitalization amount see BRRD art. 46(1)(b). 
ance with capital regulations has to be sustainable so that markets have sufficient trust in the institution's viability for at least one year. ${ }^{129}$ The latter may require a substantial over-capitalization to reassure investors that impending losses on impaired assets can be covered with certainty. ${ }^{130}$ The necessary valuation is carried out by an independent expert ${ }^{131}$ and will be further guided by regulatory technical standards drafted by the EBA. ${ }^{132}$ Obviously, and despite some inevitable pre-packaging, when resolution actually arrives, merely a preliminary valuation will be possible and a final assessment will follow only after PSI has been executed. ${ }^{133}$ To be sure, where the preliminary and the final valuation diverge, the redress foreseen in art. 75 of the BRRD does not interfere with the validity of the bail-in as it only awards compensation claims against the resolution financing mechanism (SRF). ${ }^{134}$

The institutional set-up creates two layers of insecurity from an investor's perspective. First, the degree of PSI depends on the typical blurriness of any valuation of a complex financial firm, in particular the exercise of auditors' options and discretion. ${ }^{135}$ Second, the ultimate result of PSI is only determined after compensation actions are finally adjudicated in the courts. Taken together, the two layers of uncertainty make it almost impossible to price the risk that losses accrue in a bail-in in a sufficiently precise manner ex ante. This is particularly true if PSI occurs in highly volatile markets. ${ }^{136}$

Moreover, the litigation-prone character of the bail-in tool, not only but also under the $B R R D,{ }^{137}$ adds materially to the costs of the regime's administration. ${ }^{138}$ Apart from direct litigation

${ }^{129}$ BRRD, art. 46(2). For an example see Wojcik (n 21) 111. On the importance of identifying losses accurately (no underestimation) and establishing the failed bank's capital rapidly see Avgouleas and Goodhart (n 15) 11-12.

${ }^{130}$ Zhou et al. (n 15) 19. It is at least conceivable that the leeway established by such a broad valuation target is larger than that under an approach which, like the US-regime (n 7), winds-down the failed legal entity and thus initially only has to assess in how far a bail-in is required to facilitate the spin-off of a good bank whereas losses are ultimately allocated to existing equity- and debtholders in liquidation.

131 BRRD art. 36(1).

132 Draft Regulatory Technical Standard on valuation in recovery and resolution (EBA/CP/2014/38) 1033.

133 BRRD arts. 36(2) and (9), 74. The final valuation has to be rendered as soon as possible Gardella (n 50) para 11.57; Wojcik (n 21) 110. Estimates gauge the minimum period needed for a proper valuation of a bank to be six months, Philippon and Salord (n 36) 47.

134 Wojcik (n 21) 132 This design follows prominent policy recommendations that argued in favor of a minimized role for non-specialist courts, Zhou et al. (n 15) 12. BRRD, art. 85(4) subpara 1(a) also precludes injunctive relieve.

135 Level 2 measures (see BRRD, art 36(15), 74(4)) will provide some guidance but will not eliminate auditors' latitude entirely.

${ }^{136}$ Avgouelas and Goodhart (n 15) 12 (arguing that idiosyncratic bank failures are easier to handle under favorable macro-economic conditions where they also pose less danger of contagion, whereas substantial downward adjustments of optimistic valuations lead to a published accounting discontinuity that carries over quickly to other banks and thus produces contagion).

${ }^{137}$ In recent times, legal redress was sought by bailed-in creditors for instance in the Netherlands, Matthias Haentjens, 'What Happens when a Systemically Important Institution Fails: Some Company Law Observation Re SNR Reaal', (2013) 10 ECL 70, and in Cyprus, lan Jack and Thomas Cassels, 'Cyprus: An Analysis of the Impact of the Resolution Methodology on Stakeholders', (2013) 8 CML 450, Jenny Giotaki, 'The Cypriot 'Bail-in Litigation': A First Assessment of the Ruling of the Supreme Court of Cyprus', (2013) 27 JIBFL 485, Phoebus Athanassiou, 'Valuation in Resolution and the "No Creditor Worse Off Principle"', (2014) 28 JIBFL 16, George Jacobs and David Mitchell, 'The No-Creditor-Worse-Off Principle from a Valuation Perspective: Standing in the Shoes of a Hypothetical Liquidator', (2014) 28 JIBFL 233. Litigation not only involves domestic courts, but also the ECJ, ECHR and investment arbitral tribunals, see Gardella ( $n$ 50) para 11.47.

${ }^{138}$ See also Avgouleas and Goodhart (n 15) 15 who point to the consequences if ownership of bail-inable instruments moves to specialized 'vulture' hedge funds during a crisis, because of these investors' inclination to use litigation to extract rents. 
costs, an indirect social cost may stem form resolution authorities' reputational or political concerns that might induce them to value the bank too optimistically by understating (overstating) the value of liabilities (assets). ${ }^{139}$ In this scenario, the original bail-in may prove insufficient to reach the necessary capital consolidation and require a second round of PSI with severe consequences for markets' trust in the bank's viability going forward. ${ }^{140}$

(2) No creditor worse off (NCWO)

All the problems surrounding the need to value the troubled institution are exacerbated because the BRRD guarantees investors' property rights only indirectly. Instead of prescribing a strictly proportional (necessary) degree of PSI, it requires that no debt-holder is treated worse than in regular insolvency proceedings. ${ }^{141}$ The underlying thinking is that the value of property rights is defined by insolvency law. Thus, no constitutional guarantees ${ }^{142}$ are curtailed if this lower bound is not undercut in a bail-in. From a doctrinal point of view, it is far from clear whether safeguarding financial stability would not permit more far-reaching interventions ${ }^{143}$ - after all the whole regime rests on the insight that banks are special and regular insolvency law is inapt to deal with their failure (see I), that is to say that an amplified public interest in overriding property rights exists.

What is intended to be a safe harbor for resolution authorities ${ }^{144}$ may prove as yet another source of fundamental uncertainty. The principle of NCWO requires an additional set of prognoses and assessments, because the maximum permissible PSI is determined by the outcome of hypothetical insolvency proceedings for the resolved banks. This implies to project all sorts of relevant decisions to be taken by liquidators, bankruptcy courts, and creditors on the basis of national insolvency laws that determine the ranking of claims ${ }^{145}$, the applicability of claw-back rules ${ }^{146}$ etc. ${ }^{147}$ Moreover, an inherent tension that may lead to overly cautious behavior of resolution authorities arises, because the legal limit for PSI marked by the NCWO-principle is determined by the liquidation values of assets that apply

139 The case of Italy teaches that PSI might be a hard-seller even for left-wing governments if their constituents are the ones who, for whatever reason, hold the bail-in bonds. Different scenarios can be thought of that would generate similar results for other political configurations.

140 Gardella (n 50) para 11.46.

141 BRRD art. 34(1)(g), 73. On other safeguards see Wojcik (n 21) 121-122.

142 The relevant provisions on the European level are art. 17 of the Charter of Fundamental Rights of the European Union (CFREU), [2012] OJ C326/391 and art. 1 of the Protocol of the European Convention on the Protection of Human Rights (20 March 1952), 213 UNTS 262. On these issues see Gardella (n 50) para 11.2411.32; Wojcik (n 21) 116-118. The recent ECJ case C-526/14 Kotnik and others v Državni zbor Republike Slovenije [2016] ECR I-m regarding the legitimacy of the Slovenian bail-in prior to the BRRD's entry into force does not tackle the constitutional questions on the European level but arose from a dispute regarding Slovenia's protection of property rights.

${ }^{143}$ For the broad range of legitimate objectives see CFREU art. 52(1)(1) and James and others v UK [1986] ECHR 2 para 41, 45; specifically on the balancing of individual property rights guarantees and the public interest see Spadea and Scalabrino v Italy [1995] ECHR 35, para 33 et seq.; Urbárska obec Trenčianske Biskupice v Slovakia [2007] ECHR 13, para 132.

${ }^{144}$ For this perception of NCWO as a policy option see for instance Zhou et al. (n 15) 12.

${ }^{145}$ Specifically on the resulting uncertainty and its consequences Wojcik (n 21) 126.

${ }^{146}$ Obviously, the latter can account for a significant shift in loss given default if substantial amounts can be recovered by undoing transactions that occurred before a (counterfactual) insolvency proceeding was initiated.

147 On the importance of the differences in member states' insolvency laws, Philippon and Salord ( $n$ 36) 44-46 (recommending as ultimate consequence the introduction of a pan-European insolvency regime for financial institutions). 
in bankruptcy, despite the fact that resolution may seek to preserve the failed institution as a going concern. ${ }^{148}$

The proposed amendments to the BRRD would, at least partly, mitigate the problems going forward: insofar as sufficient PSI can be achieved by bailing-in the debt instruments that satisfy the basic recognition criteria for MREL and are issued as earmarked subordinated liabilities after the reforms entered into force. The provided statutory subordination under Member States' harmonized insolvency laws ${ }^{149}$ will largely supersede the need to determine an alternative outcome in regular bankruptcy proceedings. Clearly, the extent and momentum of the reforms hinges pivotally on the adequate calibration of MREL in practice. ${ }^{150}$

\section{e) (Cross-border) banking groups}

From an investor's perspective things become particularly blurry, if the failed organization operates as a corporate group across borders, which will typically be the case for SIFIs. ${ }^{151}$ Essentially the relevant problems can be categorized into two types. First, it is far from self-evident that the execution of resolution powers is recognized across jurisdictions. This observation has implications for the choice of the overall resolution strategy, the extent of PSI for domestic investors etc (IV. 2. e) (2)). Second, where (essential) operations are carried out by affiliates of the failed institution, the recapitalization objective of the bail-in tool has to be effectively achieved for all relevant group members in order to establish the indispensable trust in the viability of those parts of the group that perform critical functions. Here again, the required group-wide coordination of the resolution strategy and its implementation in crisismode make the result of PSI hard to predict ex ante (IV. 2. e) (2)).

\section{(1) Cross-border execution of bail-in power}

At the outset, the difficulties that any execution of bail-in power across jurisdictions faces are straightforward and not limited to banking groups: if liabilities are subject to foreign law, ${ }^{152}$ sovereign debtrestructuring powers of resolution authorities have to be recognized by the pertinent foreign jurisdictions for PSI to work smoothly. Despite the theoretically broader scope of the problem, the typical realworld occurrence of this scenario will be linked to cross-border institutions where foreign liabilities are common. ${ }^{153}$ The important aspect is, once again, ${ }^{154}$ that any uncertainty as to the bail-inability of specific liabilities potentially distorts prices for both foreign and domestic financial instruments. Once the cross-border recognition of bail-in power is determined in a specific resolution case, prices have been too low/high for those foreign instruments which, from an ex ante perspective, would bear losses with

\footnotetext{
148 See Wojcik (n 21) 124.
}

${ }^{149}$ See BRRD art. 108(2) according to the Proposal for a Directive of the European Parliament and of the Council on amending Directive 2014/59/EU of the European Parliament and of the Council as regards the ranking of unsecured debt instruments in insolvency hierarchy, COM (2016) 853 final [hereinafter: BRRD amendment proposal].

${ }^{150}$ For an extensive and critical review of the regulatory framework see Tröger ( $n$ 30).

${ }^{151}$ See for instance Richard Herring and Jacopo Carmassi, 'Complexity and Systemic Risk', in Allen N. Berger, Phillip Molyneux \& John O. S. Wilson (eds.), The Oxford Handbook of Banking (2nd edn, OUP 2015) 77, 82 (table 4.1.) showing that the world's 28 largest banks on average (median) have 964 (782) subsidiaries, 60\% (61\%) of which are registered in foreign jurisdictions. On the social benefits of cross-border banking in general see Michael H. Moskow, 'Cross-Border Banking: Forces Driving Change and Resulting Regulatory Challenges' in Gerard Caprio, Jr., Douglas D. Evanoff and George G. Kaufman (eds), Cross-Border Banking: Regulatory Challenges (World Scientific Publishing Company 2006) 3, 4-5.

152 For an in-depth analysis of the treatment of shares and other securities in the conflict of laws see Maisie Ooi, Shares and Other Securities in the Conflict of Laws (OUP 2003).

${ }^{153}$ Zhou et al. (n 15) 14-15;

${ }^{154}$ For the analogous problems with a view to the discreationary exemptions in BRRD art. 44(3) see IV. 2. c) (2). 
a probability $<1$, or have been too low/high for domestic instruments that in turn exhibit higher/lower LGD quotas than expected.

The BRRD seems to solve the problem by regulatory fiat, at least among Member States. These are supposed to give full effect to a write down and conversion of capital and a bail-in that was ordered for a failed institution by the competent EU resolution authority. ${ }^{155}$ Yet, experience shows that even within the EU courts may challenge the exercise of resolution powers by foreign authorities on the grounds that they overstepped their competence, misinterpreted the scope of their empowerment etc. $^{156}$

Things get even more complicated if third countries are involved because in these cases no automatism for mutual recognition shapes behavior. From a unilateral perspective, the BRRD can only call on the responsible agents to take all necessary steps, including the use of coercive withholding rights, to make the write down or conversion become effective. ${ }^{157}$ To ensure the latter, EU institutions may negotiate international agreements that ensure inter alia the recognition of the application of resolution tools and the exercise of resolution powers. ${ }^{158}$ If no international agreement covers the respective aspects, the EBA may conclude non-binding framework co-operation agreements with third country authorities. ${ }^{159}$ If all these efforts fail and the recognition of the ordered write down or conversion of capital or bail-in of liabilities is unlikely, the respective investors do not participate in loss absorption. ${ }^{160}$ Hence, investors in both foreign and domestic bank capital have to predict the likely recognition of the exercise of resolution powers to gauge how the institution's failure might affect their position.

\section{(2) Achieving bail-in objectives for group affiliates}

If subsidiaries provide critical services, it is essential for achieving resolution objectives that trust in the viability of these operations is sustained or reestablished despite PSI. This means, that if the crisis afflicting the group does not originate at those subsidiaries (exogenous crisis) they must be able to operate unscathed through resolution. If on the other hand, the troubles for the organization were triggered at the respective subsidiaries (endogenous crisis) resolution has to ensure that these entities are adequately recapitalized in a bail-in.

To be sure, resolution objectives could be achieved rather easily in both scenarios if resolution authorities credibly committed to a single point of entry (SPE) approach under a holding structure: if resolution and PSI occur only on the level of the holding company and leave the operating affiliates largely unaffected, ${ }^{161}$ fears that sub-groups stop providing their essential services to the economy are, in principle, unwarranted. However, EU legislation applies resolution tools on a legal-entity specific basis. ${ }^{162}$ It does not favor, let alone prescribe a SPE regime, leaving the multiple point of entry (MPE) approach the default regime in case of failure of a cross-border banking group.

155 BRRD, art. 66(4).

${ }^{156}$ World Bank (n 126) 117.

157 BRRD, art 67(1)(a)(b).

${ }^{158}$ BRRD, art. 93(1). The Commission can initiate the negotiations with third countries that host significant parts of a cross border banking group.

159 BRRD, art. 97(3).

160 BRRD, art. 67(2).

161 On these key advantages of SPE regime see for instance Sommer (n 12) 217, 221; Gordon and Ringe (n 5) 1366-1368; Thomas F. Huertas, Safe to Fail (OUP 2014) 122-3; Philippon and Salord (n 36) 49.

162 For the bail-in tool BRRD art. 44(1) stipulates that it applies to institutions (credit institutions or financial firms) or other entities covered by the directive. 
The application of the bail-in tool to legal entities may lead to undesirable consequences of two types. If PSI occurs on the level of the subsidiary, the equity position of the parent may be wipedout or significantly diluted, effectively ending the group integration (de-consolidation). Such a cold exit potentially destabilizes both the parent and the already troubled subsidiary. ${ }^{163}$ If PSI occurs on the level of the parent that relies on intra-group funding through loans from an affiliate that issues debt in the market, the parent may well restore its capital base by bailing-in its obligations to the affiliate. Yet, such an internal recapitalization does not confer the losses the banking group incurred upon outside investors. Instead, it immediately creates woes for the affiliate which may not be able to resort to the bank-specific resolution regime or any other group member that guaranteed its debt. ${ }^{164}$

Even in the EU any legislative advance that would allow the exercise of resolution powers beyond the legal entity in resolution and across borders to achieve a stabilizing loss absorption by outside investors is complete science fiction. ${ }^{165}$ The real-world reaction to the problems just outlined has to be found in the coordinating efforts of resolution colleges. ${ }^{166}$ Obviously, the prediction of the outcome of such a multi-agency adjustment procedure seems already impossible, which is all the more true with regard to the actual implementation of a pre-packaged resolution strategy in a group-resolution scheme. ${ }^{167}$ National resolution authorities typically have diverging preferences that hinge on the costs and benefits the respective economies incur in resolution. ${ }^{168}$ The latter will play out in full when doomsday for the group or a significant affiliate has come, essentially forcing investors to anticipate the result of a deeply political power play.

\section{Restrictions on holdings of bail-in capital}

Whether enhanced market discipline can indeed be achieved through a regime of mandatory PSI hinges pivotally also on the demand side for capital instruments subject to bail-in. Sound banking policy requires to monitor holdings of bail-in capital from two angles. Investors have to have the necessary characteristics to bear the losses that are allocated to them in the institution's resolution and to price the risk accordingly (IV. 3. a)). They also have to have the capacity to hold bank-equity after a conversion of bail-in debt (IV. 3. b)).

163 Zhou et al. (n 15) 15.

164 Zhou et al. (n 15) 16.

165 In utopia, for instance, a failing subsidiaries' liabilities could be converted into equity of the parent to avoid de-consolidation, bail-in could extend to affiliated entities that provide funding for the failed parent, see Zhou et al. (n 15) 16.

166 BRRD, art. 88 and Final draft Regulatory Technical Standard on resolution colleges (EBA/RTS/2015/03). For a detailed description of the function, composition etc. of resolution colleges see Michael Schillig, Resolution and Insolvency of Banks and Financial Institutions (OUP 2016) paras. 16.60-16.62; Mathias Haentjens, 'Titles V and VI: Cross-border Group Resolution and Third Countries' in Gabriel Moss, Bob Wessels, and Matthias Haentjens, EU Banking and Insurance Insolvency (OUP 2017) paras. 8.08-8.10.

167 The procedure for arriving at such a scheme is laid down in BRRD arts. 91 and 92. For details see Schillig (n. 166) paras. 16.63-16.65; Haentjens (n. 166) paras. 8.13-8.18.

${ }^{168}$ For theoretical models on these aspects see Cornelia Holthausen and Thomas Rønde, 'Cooperation in International Banking Supervision', (2004) ECB Working Paper No. 316 <http://www.fsb.org/wp-content/uploads/TLAC-Principles-and-Term-Sheet-for-publication-final.pdf> accessed 20 August 2017; Patrick Bolton and Martin Oehmke, 'Bank Resolution and the Structure of Global Banks' (2016) Working Paper <http://financetheory.org/wp-content/uploads/gravity_forms/1-70ba24ead09917a027e3e47d3324b973/2016/12/Bolto-

nOehmke_BankResolution.pdf> accessed 20 August 2017; Elena Carletti, Giovanni Dell'Ariccia, and Robert Marquez, 'Supervisory Incentives in a Banking Union', (2016) IMF Working Paper WP/16/186 <https://www.imf.org/ /media/Websites/IMF/imported-full-text-pdf/exter-

nal/pubs/ft/wp/2016/_wp16186.ashx> accessed 20 August 2017. 


\section{a) Sophistication and loss bearing capacity}

First, investors in bail-in able instruments need to be able to understand the risk of bail-in, charge adequate risk premiums and thus exert meaningful debt governance vis-à-vis banks. If bail-in capital is dumped on unsophisticated (retail) investors, its highly noisy pricing will not lead to desirable market discipline. ${ }^{169}$ Second, the same investors need to have sufficient loss-bearing capacity to endure damages when their debt is written-down or converted into equity. As conversion occurs during periods of distress, new equity holdings will initially be of substantially lower value than the nominal value of prior debt holdings. Where households invest a large fraction of their wealth in banks' bail-in capital, losses incurred in PSI potentially lead to adverse social and/or psychological consequences that, in turn, may induce politicians to spare their constituents and bail-out banks instead. Where these motives are anticipated, the credibility of a regime of mandatory PSI is significantly weakened no matter which pledges legislators make at the time of promulgation. ${ }^{170}$ Third, bail-in shall not communicate instability from one financial institution to another: PSI at one bank must not endanger the financial health of other institutions as this may trigger a systemic crisis. ${ }^{171}$

Taken together, this implies that investors in bail-in able debt are ideally (1) sophisticated investors, (2) outside the banking sector whose (3) assets and liabilities are matched with regard to their maturity, i.e., there is no asset-liability mismatch. For instance, institutional investors such as insurance companies, pension funds or high-net-worth individuals represent ideal holders of bail-in able debt as they are able to incur potential short run costs of a bail-in due to their long investment horizon and may have a maturity-matched balance sheet.

Obviously, a first-best solution cannot be engineered by regulatory fiat. Yet, erroneous trends should be avoided. ${ }^{172}$ The unrestricted sale of bail-in instruments to other banks or to unsophisticated retail investors calls the objective of PSI fundamentally into question. However, meaningful restrictions on the sale of those financial instruments that will most likely be written-down or converted in resolution (subordinated debt instruments) are largely absent from the current legal framework. Neither the BRRD nor any other prudential regulation effectively prevent banks from selling their bail-inable securities to unsophisticated (retail) investors. Similarly, banks' holdings of bail-inable instruments can be limited only if they pose a risk for the holding institution's resolvability ${ }^{173}$ or violate the large exposure limits under art. 395 of the CRR. Both restrictions allow only to remedy the most glaring deviations from the social optimum. To be sure, the deduction of other banks' TLAC-instruments that G-SIBs hold form their own TLAC quota as foreseen in the European Commission's CRR amendment proposal ${ }^{174}$ will bring some relieve, but does not tackle the problems at other institutions and non-bank holders of bail-in capital.

b) Suitability of investors to hold bank equity

Even highly sophisticated investors may be found unsuitable to hold bank equity after a conversion of their debt-instruments occurred in a bail-in. In this scenario, forced sales in an illiquid market may

${ }^{169}$ For various reasons, redress in securities litigation is inapt to correct for this failure and internalize the social costs of mis-selling, see Götz and Tröger ( $n$ 45) 13-15.

${ }^{170}$ The recent events in Italy illustrate the interrelations very well, as disinclined politicians seek to widen the narrow exemptions for government intervention without minimum PSI, see already IV. 1. a).

171 Zhou et al. (n 15) 22.

${ }^{172}$ For a similar recommendation with a particular view to retail investors see Philippon and Salord (n 36) 43.

173 BRRD arts. 44(2)(5), 17(5).

${ }^{174}$ CRR amendment proposal, art. 72h, 72i; for a detailed description see Tröger (n 30) 19. 
destabilize the institution that only emerged out of resolution. ${ }^{175}$ This is particularly relevant for hedgefunds which on the one hand may be ideally situated when it comes to price discovery and risk bearing capacity, yet might not easily be sellable to politicians as owners of the banking system after bail-in. ${ }^{176}$ Yet again, excluding these funds from the pool of potential holders of bail-in capital would certainly restrict the size and liquidity of the market for such instruments.

\section{Conclusion}

In the words of a leading practitioner, the gist of the preceding analysis can be summarized as follows: "Bail-in under the BRRD is complicated". ${ }^{177}$ The simple and clear policy precept of significant, mandatory PSI has been implemented in a highly complex legal framework for bank resolution. The resolution regime established in the BRRD creates severe uncertainties that impede the assessment of the risks involved in the investment in bank capital. These difficulties mainly result from supervisory and resolution authorities' broad discretion which may lead to widely diverging outcomes. This is particularly true with regard to the determination of the trigger for resolution (supra IV. 1), the actual application of the bail-in tool and the relevant resolution powers (supra IV. 2. a), IV. 2. b)), the specification of the liabilities subject to bail-in (supra IV. 2. c)), the limits of PSI (supra IV. 2. d)), and the determination and implementation of cross-border resolution strategies (supra IV. 2. e)). In addition, the current framework is incomplete in an important respect as it does not provide satisfying holding restrictions (supra IV. 3). This under-regulation has important consequences because if bank capital is held by the "wrong" investors, PSI may produce undesirable consequences which in turn may induce decision makers succumbing to pressure from politicians who want to go easy on their constituents - to use the latitude built-in the regulatory framework to restrict the application of the bail-in tool, making PSI essentially a politically determined event.

The observation carries over to an overall skeptical assessment of whether the BRRD can achieve one of its key objectives, to reinstill adequate market discipline by making the pricing of bank capital reflect actual default risk (supra II. 1). The manifold decision alternatives that exist under the BRRD make predicting the respective outcome of resolution an endeavor akin to a 30-day weather forecast. To be sure, the regulation of TLAC and MREL provide some relief, albeit in a very limited dimension: By definition the provision of high-quality financial instruments earmarked for bail-in may enhance the predictability of who has to take the pummeling when failure hits, yet it cannot address the uncertainties associated with the highly discretionary trigger event and the determination of the specific resolution strategy and its implementation. ${ }^{178}$

The regulatory framework does not exploit all the potential for disentangling PSI from the overall resolution process (which may indeed require a lot of discretion to solve the idiosyncratic problems of bank failures on a case-by-case basis). The major impediment in this regard seems to be the BRRD's approach that-in stark contrast to the US solution-allows the failing entity to survive. Within the existing framework, bail-in can, at best, only entail an incremental improvement if the authorities involved in the resolution process are as transparent and as time consistent as possible in their stringent and impartial implementation of the BRRD and adhere to firm principles derived from policy objectives.

Yet, it is well plausible, that neither a conductive amendment of the resolution regime nor its constructive implementation is politically desired. European (universal) banks lack profitability and are

175 Zhou et al. (n 15) 14.

${ }^{176}$ Avgouleas and Goodheart (n 15) 14.

177 Simon Gleeson, 'The Architecture of the BRRD - A UK Perspective' in Danny Busch and Guido Ferrarini (eds.) European Banking Union (OUP 2015) para 12.36.

178 For a detailed discussion of the MREL's own shortfalls see Tröger (n 30) 5-19. 
further squeezed by the competition from international competitors, non-bank banks (shadow banks, fin-techs etc). On the other hand they are major employers of highly skilled labor. Raising the cost of doing business by aggravating financing conditions will, at the margin, lead to a downsizing of the sector in overbanked Europe, which inter alia entails job losses that raise political concerns. This observation should be kept in mind because it may explain many politicians proclivity to tacitly subsidize the financial sector, that might be seen as the coal and steel industry of the $21^{\text {st }}$ century, also by not rigidly compelling significant PSI. 


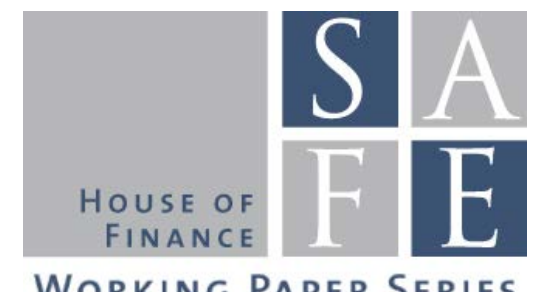

Working PAPER SERIES

\section{Recent Issues}

No. 178 Matthias Goldmann

No. 177 Michael Donadelli, Marcus Jüppner, Max Riedel, Christian Schlag

No. 176 Giuliano Curatola, llya Dergunov

No. 175 Reint Gropp, Deyan Radev

No. 174 Reint Gropp, Deyan Radev

No. 173 Merlin Kuate Kamga, Christian Wilde

No. 172 Ahmed Khalifa, Massimiliano Caporin, Michele Costola, Shawkat Hammoudeh

No. 171 Michael Donadelli, Patrick Grüning

No. 169 Max Groneck, Alexander Ludwig, Alexander Zimper

No. 168 Guido Friebel, Marie Lalanne, Bernard Richter, Peter Schwardmann, Paul Seabright

No. 167 Felix Noth, Ulrich Schüwer

No. 166 Monica Billio, Massimiliano Caporin, Roberto Panzica, Loriana Pelizzon

No. 165 Giovani Bonaccolto, Massimiliano Caporin, Roberto Panzica
United in Diversity? The Relationship between Monetary Policy and Banking Supervision in the Banking Union

Temperature Shocks and Welfare Costs

International Capital Markets with TimeVarying Preferences

International Banking Conglomerates and the Transmission of Lending Shocks across Borders

Social Centralization, Bank Integration and the Transmission of Lending Shocks

Liquidity Premia in CDS Markets

Systemic Risk for Financial Institutions of Major Petroleum-based Economies: The Role of Oil

Innovation Dynamics and Fiscal Policy: Implications for Growth, Asset Prices, and Welfare

The Impact of Biases in Survival Beliefs on Savings Behavior

Women form social networks more selectively and less opportunistically than men

Natural disaster and bank stability: Evidence from the U.S. financial system

The impact of network connectivity on factor exposures, asset pricing and portfolio diversification

Estimation and model-based combination of causality networks 